\title{
Importance of Benthic Prey for Fishes in Coral Reef-Associated Sediments ${ }^{1}$
}

\author{
Ralph C. DeFelice ${ }^{2}$ and Fames D. Parrish ${ }^{2,3,4}$
}

\begin{abstract}
The importance of open, sandy substrate adjacent to coral reefs as habitat and a food source for fishes has been little studied in most shallow tropical waters in the Pacific, including Hawai'i. In this study, in Hanalei Bay, Hawai $i$, we identified and quantified the major invertebrate fauna (larger than $0.5 \mathrm{~mm}$ ) in the well-characterized sands adjoining the shallow fringing reefs. Concurrently, we identified the fish species that seemed to make substantial use of these sand habitats, estimated their density there, sampled their gut contents to examine trophic links with the sand habitat, and made other observations and collections to determine the times, locations, and types of activity there. A variety of (mostly small) polychaetes were dominant in the sediments at most sampling stations, along with many small crustaceans (e.g., amphipods, isopods, ostracods, and small shrimps) and fair numbers of mollusks (especially bivalves) and small echinoids. Fish guts examined contained $\sim 77 \%$ of the total number of benthic taxa collected, including nearly all those just listed. However, fish consumption was selective, and the larger shrimps, crabs, and small cryptic fishes were dominant in the diets of most of the numerous predator taxa. Diets of benthic-feeding fishes showed relatively low specific overlap. The fish fauna in this area included substrate-indifferent pelagics, species with various degrees of reef relatedness, reef-restricted species, and (at the other extreme) permanent cryptic sand dwellers. Data on occurrence and movements of fishes indicated that a band of sandy substrate several tens of meters wide next to the reef was an active area for fishes, and activity was considerably different at different times of day and for fish of different ages. These results imply an important trophic role for the benthos in these near-reef habitats in support of reef-associated fishes.
\end{abstract}

Fishes associated with coral reefs have various degrees of dependence on the hard

I Funding for this research was provided to the $\mathrm{Ha}$ waili Cooperative Fishery Research Unit by the Hawai $i$ Department of Land and Natural Resources, Division of Aquatic Resources. Additional administrative and logistical support were provided by the Hawai'i Cooperative Fishery Research Unit, funded by the U.S. Geological Survey, the University of Hawai' $i$, and the Department of Land and Natural Resources. Manuscript accepted 10 March 2003.

${ }^{2}$ Hawai'i Cooperative Fishery Research Unit, University of Hawai' $\mathrm{i}$ at Mānoa, 2538 The Mall, Honolulu, Hawai i 96822.

${ }^{3}$ U.S. Geological Survey.

4 Corresponding author: phone: 808-956-8350; fax: 808-956-4238; E-mail: parrishj@hawaii.edu.

Pacific Science (2003), vol. 57, no. 4:359-384

(C) 2003 by University of Hawai'i Press

All rights reserved substrate for shelter and food (Parrish and Zimmerman 1977). Availability of habitats adjacent to reefs may play an important role in structuring reef fish communities (Ogden 1988). In Hawai'i, expansive, unvegetated sand flats, sand patches, and sandy beaches constitute a large percentage of the shallowwater marine habitat. Gosline and Brock (1960) identified members of 18 families of Hawaiian fishes associated with such habitat types. Comprehensive trophic studies in Hawai $i$ have discussed the ecological importance of open-sand areas adjacent to reefs (Hobson 1974, Parrish et al. 1985). Hobson (1974) recognized 10 species in seven families of coral reef-related teleosts that utilize unvegetated sand habitat for food or shelter. In Hawai'i (Hobson 1972, 1973, Holland et al. 1993) and other tropical areas (Starck and Davis 1966, Ogden and Ehrlich 1977, Helf- 
man et al. 1982), the major feeding grounds for some diurnally schooling, nocturnally active fishes lie away from the reef.

An important step in understanding the trophic complexity of a community is an examination of the available food base (Parrish et al. 1985). Elsewhere, shallow marine carbonate sediments are known to support diverse assemblages of invertebrates (Coull 1970, Taylor 1971, Thomassin et al. 1976, Hughes and Gamble 1977, Birtles and Arnold 1983, Jones 1984, Riddle 1988, Brown and McLachlan 1990) and to be important for some fishes as shelter and feeding grounds. A variety of fish species have been identified as predators of the invertebrates of reef-adjacent sediments. On the Great Barrier Reef, large teleosts (families Haemulidae, Lethrinidae) and elasmobranchs (Dasyatididae, Myliobatididae) are known to concentrate their feeding efforts on soft-sediment invertebrates. Jones et al. (1992) suggested that the abundance of these fishes may be more dependent on the surrounding soft sediments than on the reef itself.

Knowledge of the trophic interactions between sedimentary benthic organisms, the local fish fauna, and the adjacent coral reef is important to an understanding of the processes that structure shallow-water tropical communities (Birtles and Arnold 1983). Although there have been several extensive studies of the diets of tropical reef fish communities (Hiatt and Strasburg 1960, Randall 1967, Hobson 1974, Harmelin-Vivien 1981, Parrish et al. 1985), few researchers have attempted quantitative analysis of the distribution and abundance of prey species available, with trophic interactions in mind (Brook 1975, Parrish and Zimmerman 1977, Alheit 1982, Sorden 1982, Parrish et al. 1985, Hobson and Chess 1986).

Research into the coral reef ecosystem must include study of the fish species that have the life history and trophic characteristics that allow exploitation of the reefadjacent habitats (Parrish 1989). The goals of the research reported here were to investigate patterns of utilization of the reef-associated sedimentary habitats by fishes in a Hawaiian bay and to examine the trophic relationships among fishes and their prey in those habitats.
MATERIALS AND METHODS

\section{Study Area}

The study was conducted on the north (windward) shore of Kaua' $i$, at Hanalei Bay, in 1993-1994 (Figure 1). The bay receives freshwater input from four watersheds: $\mathrm{Ha}-$ nalei Estuary and three small streams. The center of the bay is made up of sediments that stretch from the shoreline in the southeast quadrant to beyond the mouth of the bay. Four general soft-bottom habitats are referred to here: (1) reef edge, (2) central bay, (3) the Black Hole, and (4) surf zone. Reef edge includes a band of soft-bottom habitat extending about $100 \mathrm{~m}$ out from all reef/sand interfaces. The central bay is a wide expanse of open sediment that makes up a large part of the total soft bottom. The Black Hole is a large, mud-bottom, depositional area associated with the Hanalei Estuary, extending from near the reef edge closest to the river mouth to just north of Mauna Lau patch reef. The surf zone is the narrow band $(\sim 50 \mathrm{~m})$ of sandy habitat nearest shore, extending from the Hanalei pier to Wai'oli Stream mouth.

\section{Soft-Bottom Invertebrate Sampling}

To sample potential prey of the fishes that utilize the reef-associated sediments, nine invertebrate sampling stations were permanently established in the soft-bottom habitats of the bay (Figure 1). Stations associated with reef edges (stations $1,3,5,6,7$ ) were located $50 \mathrm{~m}$ from the reef/sand interface of the closest hard substrate. The density, distribution, community structure, and taxonomic composition of invertebrate communities in the soft-bottom habitats of the bay were described based on sediment samples taken by coring and airlift suction at these nine permanent stations during July-September 1994. A detailed account (based on core samples) of the sedimentary habitats and the communities of smaller invertebrates that occupy them can be found in DeFelice and Parrish (2001). At stations $1,3,6,7,8$, and 9 (where sediment conditions permitted the procedure), a diveroperated airlift device, powered by air from a scuba tank (Chess 1978), was used to sample the larger, rarer animals known to be impor- 


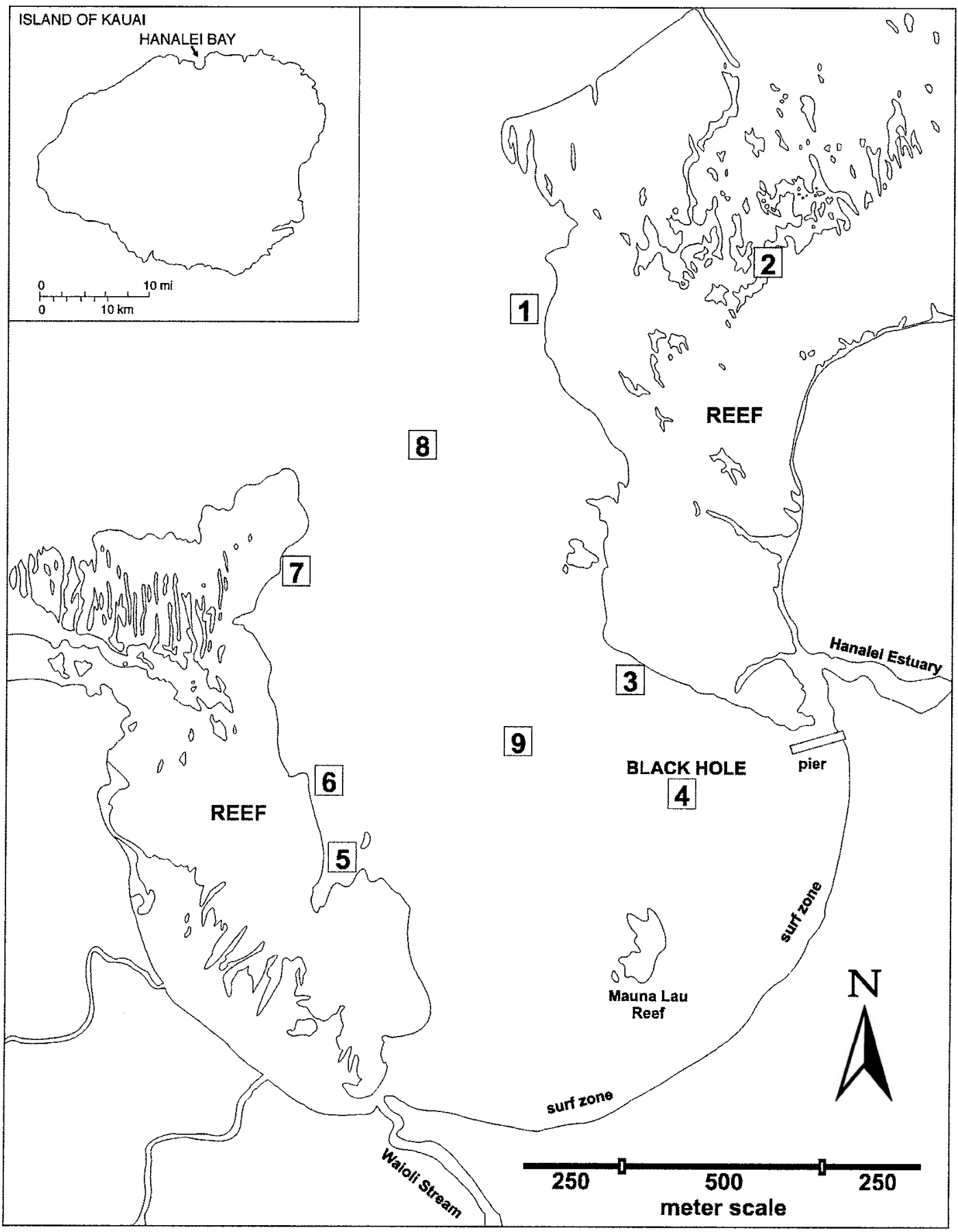

FIgURE 1. The island of Kaua'i (inset) and locations of soft-bottom sampling stations (1-9) in Hanalei Bay. 
tant in the diet of many reef fish species (Hobson 1974, Parrish et al. 1985). An open cylinder or ring $50 \mathrm{~cm}$ in diameter $\left(0.2 \mathrm{~m}^{2}\right.$ area) was pushed into the sand to a depth of $15 \mathrm{~cm}$ (roughly equivalent to the depth of the core samples), and the contents were aspirated by the airlift. A conical skirt made of $1.5-\mathrm{mm}$ square nylon mesh was attached around the open top of the cylinder and tied around the airlift tube to prevent escape of large mobile animals during operation of the device. Animals discharged by the airlift were retained in a collection bag made of $1.5-\mathrm{mm}$ square nylon mesh mounted on the airlift tube. The numerical abundance of organisms from the airlift sampling was used to augment faunal density estimates made from cores. Much of the detailed results in this paper are focused on the prey assemblage found at station 1 , but these results are certainly more widely applicable in the bay.

\section{Fish Census and Sampling}

VISUAL FISH CENSUSES. Abundance of fishes on soft substrates was assessed using underwater visual belt transect methods (V. E. Brock 1954, R. E. Brock 1982). Censuses were conducted along pairs of transects established in open sand roughly parallel to reef edges. Transect width was the maximum horizontal visibility determined by secchi disk. The first transect of each pair covered a swath extending roughly $25 \mathrm{~m}$ out onto the sand from the reef edge; the second transect covered a swath from about 50 to $75 \mathrm{~m}$ away from the reef. Both transects were about $200 \mathrm{~m}$ long. End points were marked with steel rods driven into the sand. A rod installed to each side of the centerline marked the width of the transect for night transects, and divers carried flashlights to illuminate the substrate as necessary. Orientation along the transects was maintained by swimming on compass bearings parallel to the reef edge. The sand transects overlapped with softbottom invertebrate sampling stations established in some areas (stations 1, 3, 6, and 7). Visual censuses were also conducted in the open sand habitat of the central bay. Transects were swum along a fixed compass bear- ing. The estimated 200-m distance covered was determined by counting the number of kicks made by the swimming observer. All fish encountered on all transects were counted, identified, and their lengths estimated. Observations of fish behavior, including foraging activity and approximate distance from the reef, were recorded.

HOOK-AND-LINE FISHING. Information about occurrence of fishes in general habitats was obtained by fishing from a boat with light tackle. Fishing poles were equipped with 10$\mathrm{lb}$ test line and a pair of no. 4 hooks baited with cut squid, each with a $15-\mathrm{cm}$ leader. The first hook was attached to the line so as to rest on the sediment surface, and the second hook was positioned $1 \mathrm{~m}$ above the bay floor.

Line fishing took place in three general soft-bottom habitats: reef edge, central bay, and the Black Hole. Fishing effort in reef edge and central bay habitats was associated with permanent soft-bottom invertebrate sampling stations (Figure 1). These stations were marked with buoys, and fishing took place within $25 \mathrm{~m}$ of the sampling stations. Locations of fishing events in the Black Hole were estimated by triangulation based on bearings of visible shoreline features. Fishing events were $1 \mathrm{hr}$ in duration. All fish caught were identified, measured, weighed, and retained for analysis of gut contents if appropriate.

TRAPPIng and tagging. Trapping was conducted near soft-bottom sampling stations $50 \mathrm{~m}$ from reef edges. Trap dimensions were 79 by 76 by $38 \mathrm{~cm}$ with $1.27-\mathrm{cm}$ square mesh and one funnel opening. Traps were baited with squid and allowed to fish for various soak times, usually 1-3 days. Fish collected in traps were identified, measured, weighed, and marked with internal anchor (T-bar) tags when appropriate. Fish were released immediately after insertion of the tag. Tag number, color, and position on the body were recorded. (See Friedlander et al. 1997 for details.)

BEACH SEINING. A series of beach seine hauls was made in the surf zone at various locations around the bay. The net used was $31 \mathrm{~m}$ long, $1.8 \mathrm{~m}$ high, with 6.4-mm delta mesh. On most sampling occasions, replicate 
hauls were made. Fish were identified, measured, and in some cases collected for gut content analysis.

\section{Otber Observations}

Given the patchy distributions of most fishes in sedimentary habitats, rigorous quantitative estimation of overall abundance of these fishes in the bay was not possible. Other factors, including low visibility in important habitats and the predominantly nocturnal activity of many fish species in soft-bottom habitats, contributed to the difficulty in quantifying populations. Many important observations of fishes were made incidentally during extensive time spent underwater in other activities $(\sim 200 \mathrm{hr})$. When these observations were made, quantitative data regarding fish species, estimated number of individuals and length, as well as qualitative descriptions of general location and activity, were recorded.

\section{Data Analysis}

Niche breadth in the utilization of food resources was calculated using the ShannonWiener formula (Schoener 1968). Niche overlap, $T$, was calculated as

$$
T=1.0-0.5 \sum_{i=1}^{n}\left|p_{x i}-p_{y i}\right|
$$

where $p_{x i}$ and $p_{y i}$ are the proportions by volume of the $i$ th prey category of $n$ total categories for each fish species pair $x_{i}$ and $y_{i}$.

\section{RESULTS}

\section{Benthic Invertebrates: Density and Distribution}

The best estimates of the density of identifiable invertebrate taxa larger than $0.5 \mathrm{~mm}$ appear in Appendix 1 for sediments at the nine sampled stations. These results contain a combination of data from core samples and airlift samples. For a particular taxon, the choice of source used was dependent largely on the adequacy of the sample (or the absolute number of animals) obtained by core sampling and the size of individual animals representative of that taxon. Where air lifts were taken, the numerical densities of all taxa of larger animals that could be retained by the airlift were estimated using airlift sample values, regardless of the absolute number or numerical density derived from core sampling. For the smaller taxa, the absolute number and the estimate of density (individuals per square meter) of each taxon collected by cores and by airlifts were compared. If the absolute number of individuals of a particular taxon collected in 10 cores $\left(0.19 \mathrm{~m}^{2}\right.$ total area sampled) exceeded the number collected by the 10 airlifts $\left(1.96 \mathrm{~m}^{2}\right.$ total area sampled), the estimate of numerical density was calculated using the abundance data obtained by core sampling. Within a particular taxon, numerical densities at different stations may be estimated using different collection methods. For stations where airlifts could not be taken, data from core samples only were used. Because this procedure may poorly estimate the density of larger animals, the estimates of macroanimals at these stations deserve less confidence (see footnote ${ }^{* *}$, Appendix 1).

For many of the smaller taxa in Appendix 1 , the samples from cores provide the best estimates, and the results are discussed thoroughly in DeFelice and Parrish (2001). However, a number of larger taxa, such as stomatopods, shrimps, crabs, fish, and some bivalves, are better represented in the airlift samples (footnote *, Appendix 1). These results provide important additions to the data for considering the diets of fish that forage in these habitats.

\section{Fish Distribution and Activity}

Visual Fish Censuses. A total of 455 individuals of 30 species was observed on day and/or night transects along the reef/sand interface. Overall, total density of individuals was not significantly different between day and night (Wilcoxon rank sum, $Z=1.51$, $P=0.13$ ) (Appendix 2). Density of fishes was significantly different between transects at different times and distances away from the reef (Kruskal-Wallis, $\chi^{2}=19.14, P<0.001$ ) (Appendix 2). Densities of individuals were 
higher on the 0 - to $25-\mathrm{m}$ transects than on the 50- to $75-\mathrm{m}$ transects and were not significantly different between day and night for either the near or the far transects. A single school of 100 Caranx melampygus Cuvier \& Valenciennes contributed to the high standard deviation for $50-$ to $75-\mathrm{m}$ daytime transects reported in Appendix 2. This observation was dropped from analysis in comparisons between transect time and distance from the reef. Diversity was lowest on transects $50-75 \mathrm{~m}$ from the reef $\left(H^{\prime}=0.75\right)$ during the day, but overall, diversity appeared to be similar between day and night.

Xyrichtys pavo (Valenciennes) was the fish species most commonly observed along the reef/sand interface during the day. Most species were observed less than $15 \mathrm{~m}$ from the reef edge, and all were seen within $25 \mathrm{~m}$ of the edge. Species compositions of diurnal transects at $0-25 \mathrm{~m}$ and $50-75 \mathrm{~m}$ were not significantly correlated (Spearman rank correlation, $\left.r_{s}=0.220, P>0.05 ; n=19,17\right)$. Of the eight species observed on $50-$ to $75-\mathrm{m}$ transects during the day, seven were resident sand-dwelling species.

Despite similarities in densities of total individuals, day and night transects along the reef margins $(0-25 \mathrm{~m})$ showed rather different species compositions (Spearman rank correlation, $\quad r_{s}=-0.332, \quad P<0.05, \quad n=$ 19,4). The significant negative correlation indicates that considerable species turnover occurred between day and night. Only five of the 21 species observed during the day were seen at night. Few of the species that were observed utilizing the sand habitat adjacent to the reef edge during the night were present during the day. The burrowing eel Ariosoma marginatus (Vaillant \& Sauvage) was the only cryptic species found to be active at night. Other species active during the day and night included three species of goatfish and a jack. Lutjanus kasmira (Forsskall) was the most numerous species and was observed during $100 \%$ of nocturnal censuses on transects $0-$ $25 \mathrm{~m}$ from the reef. On two other occasions, L. kasmira was observed and collected 75$100 \mathrm{~m}$ from the reef edge at night.

In the central bay, only five individuals were encountered during six $5000-\mathrm{m}^{2}$ diurnal visual censuses: three Tracbinocephalus myops (Forster \& Schneider), one Ariosoma marginatus, and one Callecbelys luteus Snyder. No fish were observed on the two $5000-\mathrm{m}^{2}$ night censuses in the central bay habitat.

Unfortunately, because of persistent low visibility, visual transects could not be conducted within the Black Hole. However, some important observations of fishes were made there. Large schools (100-200 individuals) of adult Albula sp. were observed on three occasions during the day, twice within the Black Hole and once in the softbottom habitat adjacent to station 3 . On three separate occasions, approximately 100 Caranx sexfasciatus Quoy \& Gaimard $(13 \mathrm{~cm}$ mean standard length [SL]) were observed within the Black Hole during the day in a mixed school with $\sim 100$ C. melampygus. Schools of $>200$ Pseudocaranx dentex (Bloch \& Schneider) were observed three times and a school of $\sim 200$ Upeneus taeniopterus (Cuvier) was seen once.

HOOK-AND-LINE FISHING. A total of 179 individuals of 12 species was collected by line fishing. Diel activity of fishes, as suggested by catch per unit effort (CPUE), varied in different habitats around the bay. In the central bay, a single burrowing eel, Ariosoma marginatus, was the only catch for 12 line-hours in the habitat ( $8 \mathrm{hr}$ by day, $4 \mathrm{hr}$ by night) (Table $1)$.

Although there was no significant difference between mean CPUE for day and night fishing in the Black Hole (Wilcoxon rank sum, $Z=0.95, P=0.34$ ), the species compositions of the day and night catches were not significantly correlated (Spearman rank correlation, $r_{s}=-0.275, P>0.05$ ) (Table 1). Albula sp. and Spbyrma lewini Fraser-Brunner provided the highest CPUE during the day in the Black Hole, but neither was captured there at night. Catches of Lutjanus kasmira and Lutjanus fulvus (Forster \& Schneider) were greater at night. Albula sp. was the most commonly encountered fish in the Black Hole during the day and were caught on $25 \%$ of all fishing occasions.

At reef-edge soft-bottom stations $(50 \mathrm{~m}$ from reef/sand interface) combined, CPUE increased significantly at night $(Z=-2.38$, 
TABLE 1

Mean Catch per Unit Effort (CPUE) in Number of Fish per Line-Hour, for Each Taxon at Each Research Hook-and-Line Fishing Location, Day and Night

\begin{tabular}{|c|c|c|c|c|c|c|c|c|}
\hline \multirow[b]{2}{*}{ Taxon } & \multicolumn{2}{|c|}{ Center } & \multicolumn{2}{|c|}{ Black Hole } & \multicolumn{2}{|c|}{ Edge } & \multicolumn{2}{|c|}{ Reef } \\
\hline & Day & Night & Day & Night & Day & Night & Day & Night \\
\hline Lutjanus kasmira & - & - & - & 0.33 & - & 1.50 & 8.25 & 8.00 \\
\hline Albula sp. & - & - & 0.46 & - & 0.75 & 1.90 & - & - \\
\hline Spbyrna lewini & - & - & 0.34 & - & - & - & - & - \\
\hline Lutjanus fulvus & -- & - & 0.03 & 0.40 & - & - & - & - \\
\hline Seriola dumerilii & - & - & 0.04 & - & - & 0.20 & $\ldots$ & - \\
\hline Ariosoma marginatus & - & 0.25 & - & 0.08 & - & - & - & - \\
\hline Caranx igmobilis & - & - & 0.01 & 0.10 & - & - & - & - \\
\hline Caranx sexfasciatus & - & - & 0.04 & - & - & - & - & - \\
\hline Bodianus bilunulatus & - & - & - & - & - & - & 0.25 & - \\
\hline Dasyatis sp. & - & - & - & 0.08 & - & - & - & - \\
\hline Scomberoides bysan & - & - & 0.01 & - & - & - & - & - \\
\hline Sphyraena acutipinnis & - & - & - & - & - & - & - & 0.25 \\
\hline Mean CPUE & 0.00 & 0.25 & 0.93 & 1.00 & 0.75 & 3.60 & 8.50 & 8.25 \\
\hline Total effort (line-hours) & 8.0 & 4.0 & 48.4 & 18.0 & 12.0 & 15.0 & 3.0 & 4.0 \\
\hline Total catch (no.) & 0 & 1 & 45 & 16 & 7 & 51 & 26 & 33 \\
\hline
\end{tabular}

$P=0.017$ ) (Table 1). During the day, Albula sp. was collected at stations 1 and 3. No other species was caught there by this method during the day. At night, catch of Albula sp. increased, but not significantly $(Z=-1.41$, $P=0.16$ ) (Table 1). Albula sp. were caught on $70 \%$ of all night fishing occasions at softbottom stations. Lutjanus kasmira was also very active at soft-bottom stations at night; it was caught on $40 \%$ of night fishing occasions there. On the hard reef substrate, L. kasmira actively took bait during day and night. CPUE on the reef was much greater than in soft-bottom habitats and appeared to be similar by night and day. Fish caught on the reef tended to be larger (Friedlander et al. 2002).

TRAPPING AND TAgging. Two hundred eighty-two individuals of 18 species were collected with traps at soft-bottom sampling stations. For traps set at stations $50 \mathrm{~m}$ from the reef edge, mean trap CPUE was not significantly different among traps at different sites for number of individuals (Wilcoxon rank sum, $X^{2}=6.15, P=0.10$ ). A group of traps at soft-bottom sampling stations was set and hauled concurrently with traps at the reef/sand interface (on or directly adjacent to hard substrate). CPUE by number of fish was significantly higher at soft-bottom sta- tions than at the interface at stations 1 and 6 (Table 2).

Catch at the interface showed higher diversity and a greater number of species. The species compositions of interface and softbottom station catches were not significantly correlated (Spearman rank correlation, $r_{s}=$ $-0.19, P>0.05)$. Twenty-nine percent of the 38 species caught at the interface were collected in both habitats, and $39 \%$ of species collected at the soft-bottom stations were unique to that habitat. Numerical dominance of the catch by L. kasmira was observed in both habitats, making up $66 \%$ at the interface and $48 \%$ at soft-bottom stations. Lutjanus kasmira caught in traps at soft-bottom stations were significantly smaller than those caught at the reef/sand interface (Friedlander et al. 2002). Large numbers of Heniocbus diphreutes (Jordan) were also caught in traps at soft-bottom stations. Most $H$. dipbreutes were $<5 \mathrm{~cm} \mathrm{SL}$, indicating that these fish were juveniles that probably recruited to the traps from the water column. Some other species also appeared to recruit similarly to the traps. A complete list of species caught in traps can be found in Friedlander et al. (1997).

The occurrence of individuals $>5 \mathrm{~cm}$ SL in the trap catch at soft-bottom stations 
TABLE 2

Comparison of CPUE by Number of Fish per Trap Set for Paired Research Trapping at Soft-Bottom Stations Versus Reef Interface

\begin{tabular}{llrlccr}
\hline \hline Station & Location & $n$ & CPUE & Statistic & Value & $P$ \\
\hline 1 & Interface & 15 & 0.0103 & & & \\
3 & Soft-bottom & 15 & 0.0985 & $S$ & -39.0 & $<0.001$ \\
& Interface & 7 & 0.0341 & & & \\
6 & Soft-bottom & 7 & 0.0309 & $t$ & & 0.917 \\
7 & Interface & 18 & 0.0124 & & -40.5 & 0.019 \\
7 & Soft-bottom & 18 & 0.0391 & $S$ & & \\
& Interface & 14 & 0.0670 & & -0.308 & 0.134 \\
\hline
\end{tabular}

$a$ Paired two-sample $t$-test $(t)$ or Wilcoxon signed rank test $(S)$.

TABLE 3

Species Composition of Research Trap Catch in Hanalei Bay of Fishes $>5 \mathrm{~cm}$ SL Collected at Soft-Bottom Stations Only

\begin{tabular}{lccc}
\hline \hline Species & Total No. & $\begin{array}{c}\text { Frequency of } \\
\text { Occurrence }\end{array}$ & Mean SL (cm) \\
\hline Lutjanus kasmira & 121 & 41.82 & 12.57 \\
Parupeneus porpbyreus & 5 & 9.09 & 17.48 \\
Apogon kallopterus & 2 & 3.64 & 7.25 \\
Arotbron bispidus & 2 & 1.82 & 27.20 \\
Caranx melampygus & 2 & 3.64 & 11.25 \\
Canthigaster coronata & 1 & 1.82 & 10.50 \\
Mulloidicbthys flavolineatus & 1 & 1.82 & 9.00 \\
Mulloidicbthys vanicolensis & 1 & 1.82 & 9.90 \\
Sargocentron diadema & 1 & 1.82 & 9.50 \\
Seriola dumerilii & 1 & 1.82 & 15.10 \\
Upeneus taenioptemus & 1 & 1.82 & 19.50 \\
Grand total & 138 & & \\
\hline
\end{tabular}

"Percentage of all 55 trap sets in which the species was caught.

probably reflects more accurately the regular utilization of the habitat near these stations by demersal fishes (Table 3). With fish $<5 \mathrm{~cm}$ excluded, L. kasmira accounted for approximately $87.5 \%$ of the total catch. Traps set $100 \mathrm{~m}$ from the reef on two occasions also collected L. kasmira. Ninety-seven percent of total individuals and $73 \%$ of species caught were fishes usually associated with consolidated reef habitat. Pelagic and mobile demersal species that have loose association with habitat structure made up the remainder of the catch $(\sim 3 \%)$. Adult cryptic sanddwelling species were not collected in traps.
BEACH SEINE. Fifteen taxa of fishes were collected in the surf zone using the beach seine (Table 4). Total number of individuals per haul increased significantly at night ( $t$-test, $t=-2.51, P<0.05, n=4,17$; data were $\log$ transformed). Also, species compositions by night and day were not significantly correlated (Spearman rank correlation, $r_{s}=$ $0.281, P>0.05)$. Only two taxa, Albula sp. and Hemiramphidae, were collected during the day; 15 taxa were collected in night hauls. Except for a single Seriola dumerilii (Risso) (20 cm SL), all fishes collected by this method were $<20 \mathrm{~cm} \mathrm{SL}$. 
TABLE 4

Composition of Research Beach Seine Hauls in Surf Zone Habitat

\begin{tabular}{|c|c|c|c|c|c|}
\hline \multirow[b]{2}{*}{ Taxa } & \multicolumn{2}{|c|}{ Day $(n=4)$} & \multicolumn{3}{|c|}{ Night $(n=17)$} \\
\hline & $\begin{array}{l}\text { Mean } \\
\text { No." }\end{array}$ & $\begin{array}{l}\text { Frequency of } \\
\text { Occurrence }^{b}\end{array}$ & $\begin{array}{l}\text { Mean } \\
\text { No. }{ }^{a}\end{array}$ & $\begin{array}{l}\text { Frequency of } \\
\text { Occurrence }^{b}\end{array}$ & Avg. $\mathrm{SL}^{c}(\mathrm{~cm})$ \\
\hline Caranzx sexfasciatuls & - & - & 15.35 & 70.59 & 7 \\
\hline Kublia sandvicensis & - & - & 21.35 & 47.06 & $4(382), 14(11)$ \\
\hline Clupeidae & - & - & 4.35 & 29.41 & 8 \\
\hline Albula sp. & 1.50 & 25.00 & 1.35 & 23.53 & 10 \\
\hline Mulloidicbtbys vanicolensis & - & - & 0.41 & 23.53 & 9 \\
\hline Engyprosopon bawaiiensis & - & - & 0.18 & 17.65 & 4 \\
\hline Mugil cepbahus & - & - & 0.12 & 11.76 & 17 \\
\hline Hemiramphidae & 0.25 & 25.00 & 0.29 & 11.76 & 10 \\
\hline Engraulidae & - & - & 0.24 & 11.76 & 4 \\
\hline Polydactylas sexfilis & - & - & 0.12 & 11.76 & 18 \\
\hline Pervagor spilosoma & - & - & 0.12 & 5.88 & 4 \\
\hline Acantburus triostegus & - & - & 0.12 & 5.88 & 10 \\
\hline Alectis ciliaris & - & - & 0.06 & 5.88 & 8 \\
\hline Spbyraena acutipinnis & - & - & 0.06 & 5.88 & 15 \\
\hline Seriola dumerilii & - & - & 0.06 & 5.88 & 20 \\
\hline
\end{tabular}

${ }^{a}$ Number of individuals per haul.

${ }^{b}$ Percentage of total hauls in which a taxon was collected.

$\checkmark$ Values in parentheses are number of individuals of size indicated by preceding number.

\section{Trophic Relationships between Fishes and Their Prey}

A summary of quantitative and qualitative observations on fish interactions with the habitat and benthic fauna is given for species collected in numbers large enough to warrant analysis of their diets and comparison with the composition of prey communities. The number of fish specimens collected was limited by (1) the difficulty of coordination between collection of fishes for diet analysis and collection of prey species from the sediments, and (2) the risk of disturbing this simple system by removing too many of its components from a small area over a short period of time (Hobson and Chess 1986). In many cases, the diet information available based on small sample sizes may be only suggestive of the total range of prey consumed by a species. Of fishes collected, larger species tended to feed selectively on large mobile crustaceans (e.g., shrimp and crabs) and small cryptic fishes. However, it is unlikely that the density of fish in benthic samples is representative of the total density of demersal fishes available to piscivores. Small cryptic fishes fed primarily on small epibenthic crustaceans. Relative to their proportions in the prey available, polychaetes and echinoderms were discriminated against. All prey taxa present in fish stomachs were also collected by benthic sampling, with the exception of the lizardfish Trachinocepbalus myops. Fishes ate $\sim 77 \%$ of the total number of taxa collected in samples.

Albula sp. subadults $(\leq 10 \mathrm{~cm})$ were collected in beach seine hauls at night in various locations (Table 4). Food in the stomachs of several subadults collected in the surf zone at night consisted mainly of crab megalops, amphipods, and other small crustaceans. Small individuals were also active in the surf zone during midday. Small schools $(<12$ individuals) of Albula sp. were commonly seen from the beach along the shoreline during summer months.

Of 25 adult Albula (24.8-38.5 cm SL) collected at station 1 by line fishing at night (1900-0600 hours), three fish had empty stomachs. Small shrimp, especially Ogyrididae, were numerically $(45.3 \%)$ the most 
important component of the diet (Appendix 3). Crabs (mostly Portunus sp.) were the most important taxa by volume $(37.8 \%)$. Both groups were eaten by a large fraction of all Albula specimens. Small polychaetes, especially Opheliidae, were numerically significant $(33.1 \%)$ in the diet. Bivalves and a small irregular urchin (Clypeasteridae) were probably of about equal importance as prey items.

Albula selected crabs disproportionately from available prey in the benthos (Figure 2a). Shrimp, fish, and bivalves were present in the diet in proportions roughly similar to their occurrence in the benthos. Polychaetes, an important component of the benthic community, were underrepresented in the diet of Albula. Stomatopods were present in the diets of four individuals $(18.2 \%)$ making up $5.6 \%$ of the total diet by volume, but were not present in benthic samples at station 1 . They were fairly common (up to 8.5 individuals per square meter) in benthic samples from other stations in the bay.

Twelve Lutjanus fulvus $(12.7-21.0 \mathrm{~cm} \mathrm{SL})$ collected by line fishing in the Black Hole at night (2000-0630 hours) had identifiable stomach contents (Appendix 3). Small crabs (especially portunids such as Thalamita sp.) were the dominant prey item by volume (42.9\%). Shrimp and amphipods (especially Talitroidea) were of equal importance by volume $(10.7 \%)$, but amphipods were taken in the greatest number ( $43.1 \%$ ) of all prey. A few large unidentified polychaetes were present in the diet and represented $28.5 \%$ of the total volume of all prey eaten. Small fishes may also be an important diet item in this habitat. Lutjanus fulvus specimens from the Black Hole contained prey items unlike the benthic fauna from core samples taken there from areas of relatively homogeneous silty substrate. Only two taxa found in stomachs (a portunid crab species and an acorn worm) were collected by core sampling. A wide variety of unsampled microhabitat types (e.g., sections of dead reef, areas of coral rubble, large branches and logs, mooring anchors, and patches of silty bottom) that probably support a diversity of benthic microcommunities were present in this depositional area. Lutjanus fulvus was frequently observed associated with these microhabitats and may take a large part of its prey from them.

The stomachs of 15 L. kasmira (10.0-17.9 cm SL) caught by line fishing at night (19300200 hours) at station 1 contained prey items. Small caridean shrimps, especially Ogyrididae, were clearly the dominant prey item by all measures (Appendix 3). Shrimp were found in all fish collected and composed $55.9 \%$ of the total volume of all prey consumed. Small portunid crabs, especially Portunus granulatus (H. Milne-Edwards), and small cryptic fishes appeared in only two fish specimens each, but each made up 20\% of the total diet by volume. Fishes in the diet included the small bothid Engyprosopon bawaiiensis Jordan \& Evermann and an unidentified synodontid, probably Tracbinocephalus myops. Polychaetes, amphipods, ostracods, and a single stomatopod were also eaten. Shrimp were present in the diet at approximately twice the proportion $(55.9 \%)$ of their occurrence in the benthos $(27.5 \%)$ (Figure $2 b$ ). Fish and crabs may be of about equal importance as diet items, and each made up a larger proportion of the diet than of the benthic sample. Polychaetes and amphipods were very minor items in the diet volume.

A school of 50-60 (20-23 cm SL) Mulloidichthys pflugeri (Steindachner) was observed frequently near station 1 throughout the summer of 1994. The depths at which $M$. pflugeri was observed in Hanalei Bay $(\sim 21 \mathrm{~m})$ are shallower than this species is usually reported. It is generally regarded as a relatively deep-water goatfish, commonly found deeper than $30 \mathrm{~m}$ and reported deeper than $100 \mathrm{~m}$. There appear to be no previous records of its diet or feeding. Five individuals (19.4-22.0 cm SL) were collected during the day (12001500 hours) and their stomach contents identified. Shrimp, crabs, and fish were present in all five specimens (Appendix 3). A total of 25 small cryptic fish of several species had been eaten, composing $\sim 70 \%$ of the total diet by volume. Crabs (dominantly portunids) were the second most important group by volume (13.4\%) and made up about onefourth of all prey by number. Various shrimp taxa that were common prey of other fishes 
(a) Albula sp.

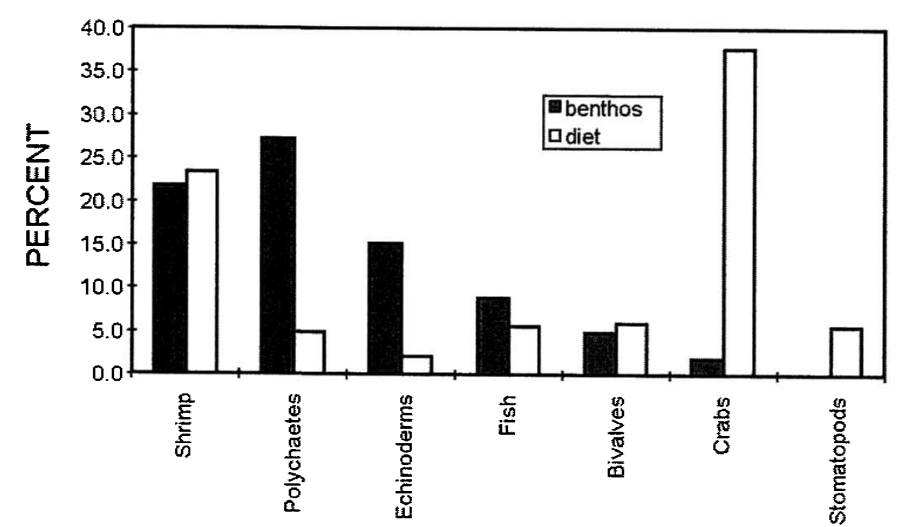

(c) Mulloidichthys pflugeri

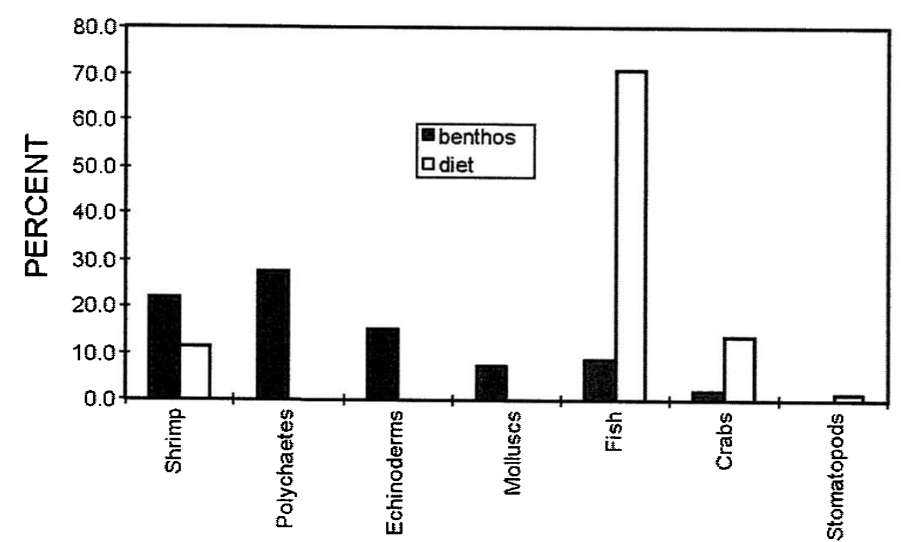

(b) Lutjanus kasmira

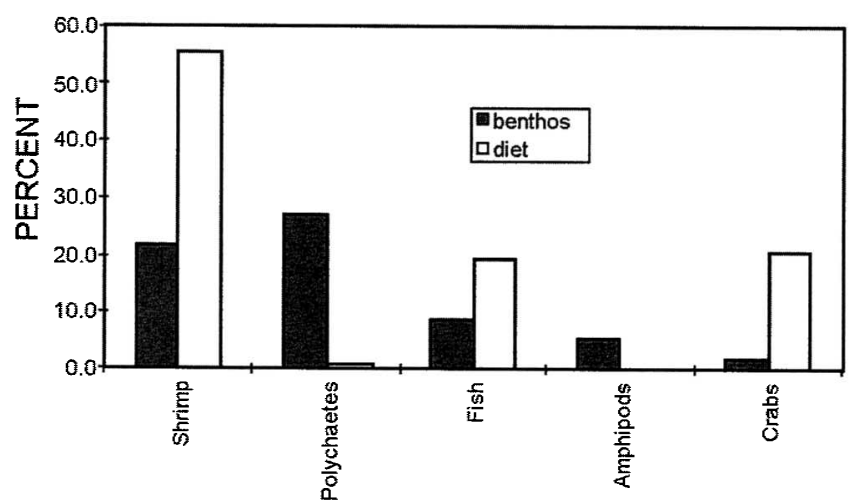

(d) Xyrichtys pavo

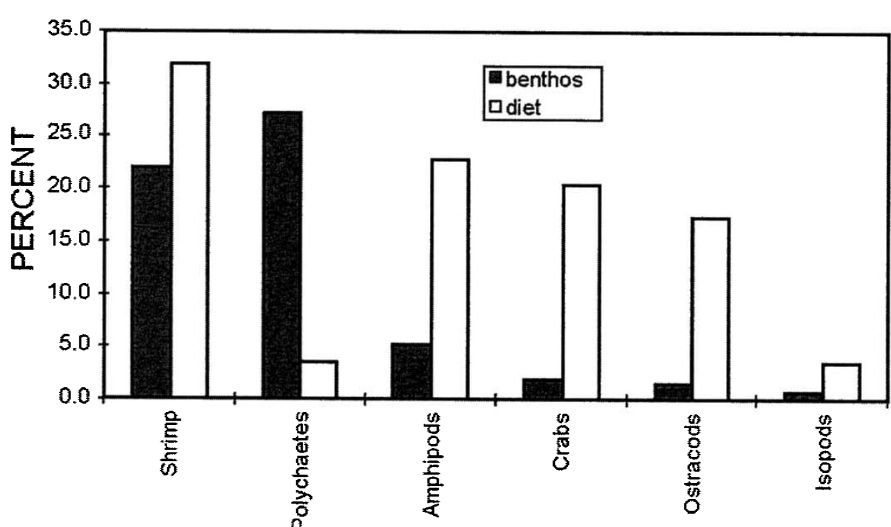

FIGURE 2. $a-d$. Comparisons between the amount of prey consumed (volumetric percentage, Appendix 3 ) and the percentage composition by volume of benthic prey available from station 1 . 
that foraged at this site were abundant in the diet of $M$. pflugeri. Several stomatopods were present in two fish specimens. Because of the nature of the foraging activity in this habitat (i.e., tight schooling) and the fact that all the fish samples were collected within a period of several days in the same location, it seems likely that the small sample of fish collected was representative of the local group. The high frequency percentage for most diet items supports this impression.

In the diet of Mulloidichtbys pflugeri, fish appeared to be selected for very strongly in relation to their proportion by volume in benthic samples (Figure $2 c$ ). Of the three identified species of cryptic fishes present, only Callionymus decoratus Gilbert and Engyprosopon bawaiiensis were present in benthic samples. The lizardfish Tracbinocephalus myops was detected during visual censuses, but probably avoided the sampling gear. Crabs were also present in the diet in a greater proportion than in the benthos.

Xyrichtys pavo had the highest overall densities (6.37 fish $/ 5000-\mathrm{m}^{2}$ transect) among fish observed on soft-bottom visual censuses during the day. The majority of these fish were juveniles or subadults $(5-10 \mathrm{~cm}$ SL), but several adults were observed. Eight individuals $(2.6-6.6 \mathrm{~cm} \mathrm{SL})$ collected over sandy substrates during the day (1000-1600 hours) contained identifiable prey items. Shrimp and crabs were found in four of the fish collected (Appendix 3). Although they represented small percentages of the number of all prey individuals identified $(8.0$ and $3.2 \%$, respectively), they provided important portions of the total volume of prey consumed (31.9 and $20.4 \%$, respectively). Small epibenthic crustaceans (amphipods and ostracods) were numerically dominant and were important by volume.

Six of the eight $X$. pavo specimens were collected near station 1 ; the remaining two were collected at stations 5 and 6 . Stomach contents were similar between stations. The diets of all specimens were pooled and compared with the benthos of the sediments at station 1 (Figure $2 d$ ). Crabs and small epibenthic amphipods and ostracods were strongly and about equally selected for by $X$. pavo. Shrimp were present in the diet in roughly the same proportion as in the benthic samples. Polychaetes were a minor diet item relative to their importance in the benthic community.

The small sharp-headed wrasse $(5-8 \mathrm{~cm}$ SL) Cymolutes lecluse (Quoy \& Gaimard) was rarely encountered in the sand habitat (Appendix 2). All five individuals seen were collected for diet analysis. Small mobile crustaceans were the dominant diet items (Appendix 3). Small shrimp were found in the stomachs of four of the five fish. Cymolutes lecluse may occasionally feed on small surfacedwelling polychaetes.

Callionymus decoratus is probably a common species at Hanalei, but due to its small size and cryptic habits it was not encountered frequently on the visual transects. The five individuals collected for diet analysis contained a wide variety of prey items (Appendix 3). All five fish contained copepods, ostracods, and amphipods. Bivalves, isopods, and polychaetes were in at least three of the fish collected, and foraminiferans, which were not included in the benthic survey, may be important as well.

Botbus mancus (Broussonet) was rarely observed in the bay. Its cryptic coloration and habits made it a very difficult species to investigate. The stomach of the one individual collected $(10.5 \mathrm{~cm} \mathrm{SL})$ contained numerous juvenile caridean shrimp, a small portunid crab, and several amphipods and isopods. One polychaete was also present.

Like the other cryptic sand-dwelling fishes, the small flatfish Engyprosopon bawaiiensis was difficult to detect visually. Although it was collected by the airlift sampling device, E. hawaiiensis was not observed along visual transects in the sand habitat. This flatfish is undoubtedly a resident in the sand habitat, but despite its apparent diurnal activity pattern, only one stomach of the five specimens collected $(2.0-7.0 \mathrm{~cm}$ SL) contained food. Twenty-five copepods, one unidentified gammaridean amphipod, and one small stomatopod were present. Ariosoma marginatus is a cryptic sand-dwelling fish that lives primarily in burrows. Results from visual census and line fishing indicate that $A$. marginatus 
is active nocturnally, foraging primarily over open-sand habitat. Two individuals were caught by line fishing at night and several individuals were seen peering out from their burrows along visual census transects during the day. Five individuals $(18.5-31.5 \mathrm{~cm} \mathrm{SL})$ were collected, two during the day and three at night. The stomachs of two individuals collected at night contained several small ogyridid shrimp.

Trachinocephalus myops was very common throughout the bay; this was the only fish species consistently observed in the central bay during the day. Trachinocephalus myops is probably active throughout the day and night, but individuals were not observed during visual counts at night. Seven individuals were collected (6.0-12.5 cm SL) for diet analysis, and stomachs of three individuals contained food, including one ogyridid shrimp, two pasiphaeid shrimps, and a single small stomatopod.

Acantburus olivaceus Bloch \& Schneider is a conspicuous herbivorous fish that was occasionally observed in the sand habitat adjacent to the reef-sand interface. During the summer, when wave activity is reduced, large (up to $10 \mathrm{~m}^{2}$ ) areas of sand bottom become blanketed by a brown algal film. Acanthurus olivaceus was often seen taking bites of sediment within these areas. The fish inadvertently takes small infaunal invertebrates along with the algae. One individual collected had numerous harpacticoid copepods and Foraminifera present in its stomach along with a large quantity of sand.

At night, subadult Caranx sexfasciatus were active in the surf zone. Two hundred sixtytwo individuals were collected in beach seine hauls, and a subsample of 15 individuals (8.3$10.6 \mathrm{~cm} \mathrm{SL}$ ) was retained for diet analysis. The stomachs of the subadult fishes contained small, well-digested, unidentified fishes and planktonic organisms. Fishes, present in $87 \%$ of stomachs, made up $95 \%$ of the diet by volume. The small size and general body shape of many of the fishes suggested that they may have been anchovies, which were common along the shore of the bay. Meroplankton (i.e., shrimp larvae and crab megalops) were numerically important in the diet and were present in $87 \%$ of the fish. Planktonic copepods were present in roughly half of the specimens and were the most numerous diet item (55\%). Several minute gammaridean amphipods were present in two of the fish examined. The pelagic nature of the diet suggests that nocturnal feeding by $C$. sexfasciatus in the surf zone has little or no direct connection with the soft-bottom benthic community.

Polydactylus sexfilis (Cuvier \& Valenciennes) was also active in the surf zone of the sandy beach habitat, and three individuals $(18 \mathrm{~cm}$ SL) were collected by seining at night near the mouth of Wai'oli Stream. The stomachs of these specimens contained various types of crabs (including portunids, hippids, and raninids); numerous small caridean shrimp and gammaridean amphipods were present in two of the three specimens. One individual had eaten several small unidentified fishes.

\section{Niche Breadth and Dietary Overlap}

Of the species analyzed, Albula sp. had the most diverse diet and consumed the highest number of prey taxa (Table 5). (Several species of fish discussed earlier are not included in the following analysis because of small sample size.) Most of the fishes consumed a wide variety of prey taxa and appeared to have somewhat similar diet diversities. Cymolutes lecluse had the lowest prey diversity and richness, but this may be an artifact of small sample size. Xyrichtys pavo was the only spe-

TABLE 5

Niche Breadth as Measured by Diet Diversity $\left(H^{\prime}\right)$ and Taxonomic Richness (S)

\begin{tabular}{lccr}
\hline \hline Fish Species & $H^{\prime}$ & $\mathrm{S}$ & $n^{\prime \prime}$ \\
\hline Albula sp. & 3.66 & 32 & 22 \\
Lutjanus kasmira & 2.85 & 16 & 15 \\
Lutjanus fulvus & 3.19 & 25 & 12 \\
Mulloidichtbys pflugeri & 2.58 & 16 & 5 \\
Xyricbtys pavo & 2.70 & 10 & 8 \\
Cymolutes lecluse & 2.39 & 7 & 5 \\
Callionymus decoratus & 3.01 & 20 & 5 \\
\hline
\end{tabular}

"Sample size. 
TABLE 6

Dietary Overlap of Fishes Collected over Soft-Bottom Habitats

\begin{tabular}{lcccccc}
\hline Species & L. kasmira & M. pflugeri & X. pavo & C. lechuse & C. decoratus & L. fulvus $^{a}$ \\
\hline Albula sp. & 0.581 & 0.305 & 0.426 & 0.367 & 0.186 & 0.245 \\
L. kasmira & - & 0.484 & 0.346 & 0.312 & 0.123 & 0.116 \\
M. pflugeri & & - & 0.045 & 0.032 & 0.023 & 0.160 \\
X. pavo & & & - & 0.733 & 0.137 & 0.139 \\
C. lecluse & & & & - & 0.110 & 0.114 \\
C. decoratus & & & & & - & 0.063 \\
\hline
\end{tabular}

"Specimens collected near station 4. All other species collected from station 1 .

cies not found to eat polychaetes, and mollusks were consumed by only Albula sp. and Callionymus decoratus.

Dietary overlap of fishes collected at station 1 was generally low (Table 6). The highest overlap was detected between the two labrids, Xyricbtys pavo and Cymolutes lecluse. These two species ate primarily ostracods, ogyridid shrimp, small portunid crabs, and a species of unidentified gammarid amphipod. The diet of the introduced snapper Lutjanus kasmira, overlapped somewhat with that of Albula sp. and less so with that of Mulloidichthys pflugeri. Lutjanus kasmira and Albula sp. had stomatopods, ogyridid shrimp, and portunid crabs in common in their diet, and $L$. kasmira and $M$. pflugeri shared stomatopods, penaeid shrimp, portunid crabs, and small cryptic fishes. The overlap between Albula sp. and $M$. pflugeri was low. The lowest dietary overlaps appear to be between $M$. pflugeri and the much smaller cryptic sand-dwelling fishes. These small fishes were an important prey item for the goatfish, and small crustaceans, such as amphipods and ostracods, important for the cryptic fishes, were not present in the stomach of the $M$. pflugeri examined.

Dietary overlap between L. fulvus, collected near station 4, and all other species, collected at station 1 , was consistently low, reflecting the difference in prey availability at the two stations. Five of the prey taxa consumed by $L$. fulvus near station 4 , which accounted for $\sim 73 \%$ of its total diet by volume, were not present in the stomachs of fishes or benthic samples collected at station 1 .

\section{DISCUSSION}

\section{Functional Groups of Fishes}

The species composition of fish communities is influenced by the need to capture the prey and avoid the predators that are characteristic of the habitat (Hobson 1974). Trophic studies show that fishes employ a wide variety of morphological adaptations and feeding strategies (Hiatt and Strasburg 1960, Keast and Webb 1966, Randall 1967, Hobson 1974). Clearly, morphology constrains the diet to a subset of what is available, and behavioral adaptation allows the fish to further refine its selection (Hart 1986). Based on observed utilization of habitats, fishes were divided into three main categories with two secondary categories (Table 7).

All fish taxa directly observed or detected by remote techniques over the soft-bottom habitats described here are listed in Appendix 4. Primary and secondary groupings, with regard to degree of utilization of soft-bottom habitats, as well as general diel patterns of activity in such habitats, are included. A total of 39 taxa was found using the sand habitat to some degree.

SAND-RESTRICTED FISHES. Sandrestricted species are strongly substrate oriented and do not associate regularly with reefs. They include two groups of fishes, cryptic sand dwellers and mobile demersals. Cryptic sand dwellers rely on sedimentary habitats for food and shelter and are inconspicuous because of cryptic coloration and covert behavior. This secondary category includes flatfishes, lizardfishes, razorfishes, and 
TABLE 7

Functional Groups of Fishes Observed Utilizing Soft-Bottom Habitats (Adapted from Parrish and Zimmerman 1977)

\begin{tabular}{|c|c|c|}
\hline Fish Assemblage & Functional Group & Common Families \\
\hline \multirow[t]{2}{*}{ Sand-restricted } & Cryptic sand dweller & $\begin{array}{l}\text { Labridae (razorfishes), Bothidae, Synodontidae, } \\
\text { Callionymidae }\end{array}$ \\
\hline & Mobile demersal & Sphyrnidae, Albulidae, Polynemidae \\
\hline \multirow[t]{2}{*}{ Sand-related } & Reef-related & Mullidae, Lutjanidae \\
\hline & Reef-restricted & Acanthuridae, Chaetodontidae \\
\hline \multirow[t]{2}{*}{ Substrate-indifferent } & Large pelagics $(>20 \mathrm{~cm})$ & Carangidae \\
\hline & Small pelagics $(<20 \mathrm{~cm})$ & $\begin{array}{l}\text { Carangidae (subadults), Clupeidae, Atherinidae, } \\
\text { Hemiramphidae }\end{array}$ \\
\hline
\end{tabular}

burrowing eels. Mobile demersals are wideranging fishes that are not cryptic in coloration or behavior, but probably rely exclusively on soft-bottom habitats for feeding. Such fishes that lack the capacity for concealment and forage over sand expanses during the day may reduce the threat of predation through other means (e.g., large size or high visual acuity) (Hobson and Chess 1986). This group includes fishes such as bonefishes, moi, mullet, and hammerhead shark pups.

Three types of cryptic sand-dwelling fishes-benthic, burrowing, and hoveringwere found in Hanalei. The benthic fishes (Bothus mancus, Engyprosopon bawaiiensis, Trachinocephalus myops, and Callionymus decoratus) all displayed similar cryptic coloration. For these species, cryptic coloration may afford some defense against predation, but not complete protection. Engyprosopon bawaiiensis, T. myops, and C. decoratus were all present in the stomachs of the larger Mulloidichtbys $p f u$ geri. The cryptic coloration of adult $B$. mancus and $T$. myops may allow greater success as ambush predators; stomachs of these two species contained mobile macrocrustaceans.

The burrowing eels Ariosoma marginatus and Callechelys luteus were not collected in numbers large enough to permit quantitative diet analysis. The stomachs of several specimens collected were empty. Ariosoma marginatus and $C$. luteus were both observed in the entrance of burrows during the day throughout the bay. When approached, individuals retreated into their burrows, frequently covering the entrance. Ariosoma marginatus was collected by line at night, suggesting that these fishes forage nocturnally in the open sand for small invertebrates and fishes. Callecbelys luteus may have similar foraging habits.

The razorfishes Xyricbtys pavo and Cymolutes lecluse displayed similar daytime behavior and possess moderate cryptic coloration. Juvenile $X$. pavo were very commonly encountered hovering just above the sand bottom, drifting to and fro with the motion of the overlying water column. To larger predators, these juveniles may resemble small pieces of drift algae or other debris. Razorfishes are highly compressed, moderately elongate fishes with a steep, keeled forehead (Myers 1991). When approached, individuals dive headfirst into the substrate, burying themselves completely. It also appeared that once beneath the substrate, the fishes moved horizontally, perhaps as a mechanism of escape from a predator that is capable of excavating the sediment.

Fishes categorized as mobile demersals were observed throughout the bay. Albula sp. was active during the day and night and foraged in large schools along reef edges and within the Black Hole. These fish excavate the soft sediment with their conical snout, and an inferior lower jaw allows prey to be taken close to the sand bottom. Juvenile Spbyrna lewini forage for prey in a similar manner, digging for individual prey with their shovel-like snout. In addition to a snout and mouth orientation similar to that of Albula sp., Polydactylus sexfilis possesses a pair of elongated pectoral fin rays that allow the fish 
to feel for prey in the substrate. Upeneus taeniopterus was not associated with reef substrate. Like all goatfishes, $U$. taeniopterus possesses a pair of chin barbels containing taste buds that probe the sandy bottom for prey (Holland 1976). When prey are detected, the fish may take a large mouthful of sediment and winnow prey organisms from other material, expelling sand and debris through the gill openings.

SAND-RELATED FISHES. Sand-related fishes are not confined to the soft-bottom habitat. Fishes in both the reef-related and reef-restricted subcategories are obligate users of hard reef substrate. Reef-related fishes seek shelter on the reef during the day and may form large, diurnal-resting schools. These fishes may feed on the reef to some degree, but seem to rely heavily on the soft substrate as a foraging ground. Activity on the soft-bottom habitat is primarily nocturnal, and species in this group may possess specialized structures, such as the barbels of goatfishes, that facilitate excavation of infaunal prey. Reef-restricted fishes may engage in short forays over the soft substrate close to reef edges, but compared with reef-related species the sand habitat seems to be less important. The hard substrate of the reef provides foraging and shelter space, and many species possess adaptations that allow exploitation of the reef and its prey. Members of this group occasionally observed over softbottom habitat included surgeonfishes and butterflyfishes.

Lutjanus kasmira and L. fulvus, two species of introduced snappers (Lutjanidae), were important predators upon soft-bottom invertebrates in the bay. These snappers do not appear to possess any special morphological adaptations for successful exploitation of the habitat. Both species form diurnal schools along reef edges and forage nocturnally away from the reef at night. Lutjanus kasmira was detected over the sand bottom associated with the reef edges of the outer bay; L. fulvus was more commonly observed in the soft bottom of the Black Hole. Both species are probably visual predators that strike individual prey along the sand surface or in the water column.
Mulloidichtbys flavolineatus (Lacepède) and M. vanicolensis (Valenciennes) are goatfishes that school diurnally over the reef and forage nocturnally over sand bottoms. Sorden (1982) attempted to examine the food base in sandy areas available to goatfishes (Mullidae) in the Northwestern Hawaiian Islands. The diet of $M$. flavolineatus that she collected was composed mainly of polychaetes found in her sand samples. In a study on $\mathrm{O}^{6} \mathrm{ahu}$, Holland et al. (1993) documented repeated nocturnal migrations of $M$. flavolineatus to the same sand area, identified as an important feeding ground. Although diurnal schools of both species were present consistently along most reef edges at Hanalei Bay, especially at station 1 , the nocturnal foraging grounds of these goatfishes were not discovered. Unlike the other goatfishes observed in Hanalei, $M$. pflugeri was a very active diurnal feeder in the sand habitat around station 1. Individuals within the school foraged in a tight group, and large areas of sediment were disturbed as the foraging school moved slowly through the habitat.

SUBSTRATE-INDIFFERENT FISHES. Large substrate-indifferent pelagic fishes have large daily ranges and move freely through the water column between habitat types. They were typically observed in small schools $(<10$ individuals) or alone. These fishes do not rely on any habitat for shelter and may feed freely from the substrate or the water column. This group consists mainly of jacks. Small pelagics include juveniles and subadults of larger species and the typically surface-oriented "baitfishes," such as sardines and halfbeaks, that also utilize the water column as shelter. These fishes typically form larger schools $(>100)$ in the water column, possibly as a defense against predation.

\section{Habitat Utilization}

It is obvious that in Hanalei Bay there is complex interaction between fishes and habitats. Many fishes make routine movements between and within habitats throughout the bay. Soft-bottom habitats along reef edges, within the Black Hole, and along the surf zone play an important role in the life history 
of many fishes, including the majority of species identified as having fishery resource value (Friedlander et al. 1997).

The Black Hole appears to provide diurnal shelter for a variety of fishes. Usually visibility within the Black Hole was very poor due to suspended sediment in the water column. Large schools of subadult jacks, including Caranx melampygus, C. sexfasciatus, and Pseudocaranx dentex, were observed within the Black Hole during the day. Upeneus taeniopterus, Lutjanus fulvus, and small Sphyrna lewini were also present in large numbers. The Black Hole is probably an important pupping ground for the hammerhead shark. At night, small jacks appeared to move out of the Black Hole to feed in the surf zone, but $U$. taeniopterus and the small sharks remained close to the Black Hole. Occasionally, small $U$. taeniopterus were observed as far away as station 1 at night, but otherwise there was little indication that many individuals migrated nocturnally. Observations of $L$. fulvus in the Black Hole suggested that this habitat might be important for adults as well as juveniles. Small individuals $(5-7 \mathrm{~cm})$ were associated with the limited available hard structure (e.g., logs, mooring anchors, and portions of reef). No L. fulvus of this size class were observed on the contiguous reef (Friedlander et al. 1997). Previous studies reported that juveniles are common and abundant inside $\mathrm{Ha}$ nalei Estuary and are associated with dead reef bottoms (Harrison et al. 1991). The surf zone appears to be an important nocturnal habitat for many fishes (see Table 4). Juvenile Kublia sandvicensis (Steindachner) were abundant in the beach seine hauls at night. These flagtails apparently move out of estuary and stream mouths, where they spend their days, to feed in the surf zone. Adult $K$. sandvicensis were also nocturnally active in the surf zone. A large diurnally resting school of adult $K$. sandvicensis was present in a small cave on the Mauna Lau patch reef throughout the study. This reef is close to the beach seine sampling site and may have been the source of these adult fish. Juvenile Albula sp. were collected in the surf zone during the day and night, indicating that they may be resident in this habitat; they were not observed elsewhere in the bay. In other areas, surf zones of sandy beaches are known to act as important nursery areas for fishes (Modde 1980, Modde and Ross 1981 [Gulf of Mexico]; Lenanton et al. 1982, Robertson and Lenanton 1984, Lenanton and Caputi 1989 [Australia]). The role of surf zones as nursery areas for Hawaiian fishes should be further explored and perhaps considered when making management and development decisions.

Several sand-related species, discussed earlier, make regular movements at dusk from the reef-edge habitat to the adjacent sand habitat. Tagging of Lutjanus kasmira indicated that long-distance movements were rare (Friedlander et al. 2002). However, results of the tagging program and other methods described earlier indicate that $L$. kasmira engages in routine, nocturnal migrations away from the reef substrate to forage in the soft-bottom habitat, up to at least $100 \mathrm{~m}$ from the reef/sand interface. These fish apparently have high fidelity to home range on the hard substrate and return to the same nocturnal foraging grounds on a regular basis. Larger L. kasmira appear to forage on the hard substrate almost exclusively. Smaller individuals may be relegated to the surrounding soft-bottom habitats. Albula sp., a mobile demersal fish, appeared also to utilize the softbottom habitat adjacent to the reef edge. Large schools of Albula sp. were observed during the day along the reef edge near station 3 and in the Black Hole (near station 4). At night, Albula sp. apparently moved along reef edges to station 1, where it was frequently caught by hook-and-line fishing. During the day, larger substrate-indifferent fishes (mostly jacks) were observed patrolling reef edges.

Benthic sampling in the sediments along reef edges and in the central bay revealed the presence of potential prey items throughout the bay (Appendix 1). Most fish diets were compared with the prey assemblage at station 1. Larger crustaceans and small fishes were important in the diet of fishes feeding in the sediment habitat. Fishes and crabs appeared to be taken most selectively, especially by the larger fishes collected. Predation by fishes is probably an important source of mortal- 
ity among the sand-dwelling portunid crabs Portunus sanguinolentus (Herbst) and $P$. granulatus. Cryptic behavior and coloration of small fishes was not an effective defense against predation by Mulloidicthys pflugeri; fishes made up $71 \%$ of its diet by volume. Polychaetes, although abundant in the sediments, were not heavily preyed upon by fish examined in this study. Many of the polychaetes collected were very small and perhaps difficult for fishes to remove from the sediments. Mulloidicthys flavolineatus at Hanalei formed large diurnal schools along the reef edge near station 1, but was not observed foraging in the sediments there. Polychaetes are probably an important prey item for the crabs and shrimp that were eaten by fishes feeding in the sediments.

Despite the small diet sample sizes available for analysis, some trends in dietary diversity and overlap emerged. At station 1, Albula sp. and Callionymus decoratus had the most diverse diets and consumed the greatest number of prey species. Dietary overlap between these two species was very low, reflecting constraints associated with their different morphologies. The highest dietary overlap was between the two resident wrasses, Cymolutes lecluse and Xyrichtys pavo, which have very similar morphology and behavior.

It is difficult to speculate on competition for food between L. kasmira and native species. The fish that showed the largest calculated dietary overlap with L. kasmira was Albula sp. Because the diversity of large prey available was low, considerable similarity was expected. Overall, dietary overlap indices between the snapper and other species were relatively low, and there is no indication that food resources are limiting in this habitat. Oda and Parrish (1982) found little overlap between L. kasmira and a soldierfish collected together. Lutjanus fulvus, collected at the Black Hole, had low overlap with the fishes collected at station 1 . No published information is available about the diet or habitat preferences of adult L. fulvus in Hawai'i. In Hanalei Bay, the two snappers appear to segregate themselves by habitat and therefore rarely interact.

It appears that juvenile, subadult, and adult
Lutjanus kasmira display ontogenetic differences in habitat utilization. At station 1, subadult and adult individuals compose the daytime schools, but at night many of the subadults move off the reef to feed in the adjacent sediments, and larger adults remain on the reef to feed. Small juveniles, which take mainly planktonic organisms, were rarely found on the contiguous reef during the day or night. Juveniles were concentrated around larger reef debris surrounded by sand (e.g., dislodged coral heads) or patch reefs, where conspecific adults were not present (R.C.D., pers. obs.). These juveniles are capable of crossing wide expanses of open sand (Frederick 1997) and may use these fragmented habitats as staging areas, eventually moving to the reef when large enough to escape predation. It is not clear whether the snappers preferentially recruit to these fragmented habitats or whether they are the only places the recruits survive because of reduced predation pressure. Whether adult L. kasmira prey directly upon conspecific juveniles remains unknown. Adults of some species may also affect juveniles indirectly (e.g., by influencing growth [Jones 1987]).

Clearly, trophic relationships are important in structuring animal communities. The relationship between reef fish and the prey that inhabit adjacent sedimentary habitats may be important in Hawai'i. This underappreciated link between the off-reef production of open-sand habitats and reef fish communities is also evident in temperate Atlantic systems (Lindquist et al. 1994). The reef/sand interface appears to be particularly important in Hanalei Bay. Habitat boundaries, or edges, providing abruptly altered physical regimes, biomass, and community structure, attract predators and prey and provide sites for spawning and migration (Ogden 1988). Unfortunately, most research into the ecology of coral reefs has ignored softsediment communities and focused on the hard substrata of reefs and the associated fauna. Surf zones and unusual habitats, such as the Black Hole in Hanalei Bay, may also provide important support for fish communities in many tropical areas. These communities may be particularly sensitive 
to anthropogenic stresses, which may cause changes in diversity and abundance of invertebrates. Recent concerns about the potentially adverse effects of increased coastal development and overfishing on nearshore fish stocks and the coral reef ecosystem in general underscore the need for continued research exploring important ecological linkages between habitat types and interacting fish communities.

\section{ACKNOWLEDGMENTS}

J. H. Bailey-Brock and E. A. Kay provided advice during this study and reviewed early drafts of the manuscript. J. L. Frederick and J. D. Peterson assisted in the field, and the Hanalei Bay Resort and Kaua'i National Wildlife Refuge Complex (U.S. Fish and Wildlife Service) provided logistical support. Special thanks to A. M. Friedlander for support in the field and valuable criticisms regarding all aspects of this research. This research partially fulfilled the requirements for a master's degree in zoology from the University of Hawai'i at Mānoa, Honolulu, to R.C.D.

\section{Literature Cited}

Alheit, J. 1982. Feeding interactions between coral reef fishes and the zoobenthos. Proc. 4th Int. Coral Reef Symp. 2:545-552.

Birtles, A., and P. Arnold. 1983. Between the reefs: Some patterns of soft substrate epibenthos on the Central Barrier Reef Shelf. Pages 159-163 in J. T. Baker, R. M. Carter, P. W. Sammarco, and K. P. Stark, eds. Proceedings, Inaugural Great Barrier Reef Conference, Townsville. James Cook University Press, Australia.

Brock, R. E. 1982. A critique of the visual census method for assessing coral reef fish populations. Bull. Mar. Sci. 32:269-276.

Brock, V. E. 1954. A preliminary report on a method of estimating reef fish populations. J. Wildl. Manage. 18:297-308.

Brook, I. M. 1975. Some aspects of the trophic relationships among the higher consumers in a seagrass community (Tbalassia testudinum Konig) in Card Sound, Florida.
Ph.D. diss., University of Miami, Miami, Florida.

Brown, A. C., and A. McLachlan. 1990. Ecology of sandy beaches. Elsevier Science Publishers B.V., Amsterdam.

Chess, J. R. 1978. An airlift sampling device for in situ collecting of biota from rocky substrata. Mar. Technol. Soc. J. 12:20-23.

Coull, B. C. 1970. Shallow water meiobenthos of the Bermuda Platform. Oecologia (Berl.) 4:325-357.

DeFelice, R. C., and J. D. Parrish. 2001. Physical processes dominate in shaping invertebrate assemblages in reef-associated sediments of an exposed Hawaiian coast. Mar. Ecol. Prog. Ser. 215:121-131.

Frederick, J. L. 1997. Post-settlement movement of coral reef fishes and bias in survival estimates. Mar. Ecol. Prog. Ser. 150:65-74.

Friedlander, A. M., R. C. DeFelice, J. D. Parrish, and J. L. Frederick. 1997. Habitat resources and recreational fish populations at Hanalei Bay, Kauai. Unpublished project report by the Hawai' $i$ Cooperative Fishery Research Unit to the Hawai'i Division of Aquatic Resources, 1151 Punchbowl Street, Room 330, Honolulu, Hawai'i 96813. 320 pp.

Friedlander, A. M., J. D. Parrish, and R. C. DeFelice. 2002. Ecology of the introduced snapper Lutjanus kasmira (Forsskal) in the reef fish assemblage of a Hawaiian bay. J. Fish Biol. 60:28-48.

Gosline, W. A., and V. E. Brock. 1960. Handbook of Hawaiian fishes. University of Hawai'i Press, Honolulu.

Harmelin-Vivien, M. L. 1981. Trophic relationships of reef fishes in Tulear (Madagascar). Oceanol. Acta. 4:365-374.

Harrison, J. T., R. A. Kinzie III, G. C. Smith, P. Y. Tamaru, D. Heacock, L. Honigman, A. Newman, J. D. Parrish, and M. Kido. 1991. Baseline studies of the Hanalei River estuary and other north shore rivers, Kauai. Unpublished final report to the Hawai'i Division of Aquatic Resources, 1151 Punchbowl Street, Room 330, Honolulu, Hawai'i, 96813. 165 pp.

Hart, P. J. B. 1986. Foraging in teleost fishes. Pages 211-235 in T. J. Pitcher, ed. The 
behavior of teleost fishes. Croom Helm, Ltd., London.

Helfman, G. S., J. L. Meyers, and W. N. McFarland. 1982. The ontogeny of twilight migration patterns in grunts (Pisces, Haemulidae). Anim. Behav. 30:317-326.

Hiatt, R. W., and D. W. Strasburg. 1960. Ecological relationships of the fish fauna on coral reefs of the Marshall Islands. Ecol. Monogr. 30:65-127.

Hobson, E. S. 1972. Activity of Hawaiian reef fishes during the evening and morning transitions between daylight and darkness. Fish. Bull. 70:715-740.

- 1973. Diel feeding migrations in tropical reef fishes. Helgol. Wiss. Meeresunters. 24:361-370.

. 1974. Feeding relationships of teleost fishes on coral reefs in Kona, Hawaii. Fish. Bull. 72:915-1031.

Hobson, E. S., and J. R. Chess. 1986. Relationships among fishes and their prey in a nearshore sand community off southern California. Environ. Biol. Fishes 17:201226.

Holland, K. N. 1976. A behavioral and electrophysiological investigation of the taste function of the barbels of a Hawaiian goatfish. M.S. thesis, University of Hawai' $i$ at Mānoa, Honolulu.

Holland, K. N., J. D. Peterson, C. G. Lowe, and B. M. Wetherbee. 1993. Movements, distributions and growth rates of the white goatfish Mulloides flavolineatus in a fisheries conservation zone. Bull. Mar. Sci. 52:982992.

Hughes, R. N., and J. C. Gamble. 1977. A quantitative survey of the biota of intertidal soft substrata on Aldabra Atoll, Indian Ocean. Philos. Trans. R. Soc. Lond. 279:327-355.

Jones, A. R. 1984. Sedimentary relationships and community structure of benthic crustacean assemblages of reef-associated sediments at Lizard Island, Great Barrier Reef. Coral Reefs 3:101-111.

Jones, G. P. 1987. Competitive interactions among adults and juveniles in a coral reef fish. Ecology 68:1534-1547.

Jones, G. P., G. J. Ferrell, and P. F. Sale. 1992. Fish feeding and dynamics of soft- sediment mollusc populations in a coral reef lagoon. Mar. Ecol. Prog. Ser. 80:175190.

Keast, A., and D. Webb. 1966. Mouth and body form relative to feeding ecology in the fish fauna of a small lake, Lake Opinicon, Ontario. J. Fish. Res. Board Can. 23:1845-1874.

Lenanton, R. C. J., and N. Caputi. 1989. The roles of food supply and shelter in the relationship between fishes, in particular Cnidoglanis macrocepbalus (Valenciennes), and the detached macrophytes in the surf zone of sandy beaches. J. Exp. Mar. Biol. Ecol. 128:165-176.

Lenanton, R. C. J., A. I. Robertson, and J. A. Hansen. 1982. Nearshore accumulations of detached macrophytes as nursery areas for fish. Mar. Ecol. Prog. Ser. 9:51-57.

Lindquist, D. G., L. B. Cahoon, I. E. Clavijo, M. H. Posey, S. K. Bolden, L. A. Pike, S. W. Burk, and P. A. Cardullo. 1994. Reef fish stomach contents and prey abundance on reef and sand substrata associated with adjacent artificial and natural reefs in Onslow Bay, North Carolina. Bull. Mar. Sci. 55:308-318.

Modde, T. 1980. Growth and residency of juvenile fishes within a surf zone habitat in the Gulf of Mexico. Gulf Res. Rep. $6: 377-385$.

Modde, T., and S. T. Ross. 1981. Seasonality of fishes occupying a surf zone habitat in the northern Gulf of Mexico. Fish. Bull. 78:911-922.

Myers, R. F. 1991. Micronesian reef fishes. Coral Graphics, Guam.

Oda, D. K., and J. D. Parrish. 1982. Ecology of commercial snappers and groupers introduced to Hawaiian reefs. Proc. 4th Int. Coral Reef Symp. 1:59-67.

Ogden, J. C. 1988.'The influence of adjacent systems on the structure and function of coral reefs. Proc. 6th Int. Coral Reef Symp. 1:123-129.

Ogden, J. C., and P. R. Ehrlich. 1977. The behavior of heterotypic resting schools of juvenile grunts (Pomadasyidae). Mar. Biol. (Berl.) 42:273-280.

Parrish, J. D. 1989. Fish communities of interacting shallow-water habitats in tropical 
oceanic regions. Mar. Ecol. Prog. Ser. 58:143-160.

Parrish, J. D., and R. J. Zimmerman. 1977. Utilization by fishes of space and food resources on an offshore Puerto Rican coral reef and its surroundings. Proc. 3rd Int. Coral Reef Symp. 1:297-303.

Parrish, J. D., M. W. Callahan, and J. E. Norris. 1985. Fish trophic relationships that structure reef communities. Proc. 5th Int. Coral Reef Congr. 4:73-78.

Randall, J. E. 1967. Food habits of reef fishes of the West Indies. Stud. Trop. Oceanogr. (Miami) 5:665-847.

Riddle, M. J. 1988. Patterns in the distribution of macrofaunal communities in coral reef sediments on the central Great Barrier Reef. Mar. Ecol. Prog. Ser. 47:281-292.

Robertson, A. I., and R. C. J. Lenanton. 1984. Fish community structure and food chain dynamics in the surf-zone of sandy beaches: The role of detached macrophyte detritus. J. Exp. Mar. Biol. Ecol. 84:265283.

Schoener, T. W. 1968. The anolis lizards of Bimini: Resource partitioning in a complex fauna. Ecology 49:704-726.

Sorden, C. T. 1982. Trophic relationships of goatfishes (Family Mullidae) in the Northwestern Hawaiian Islands. M.S. thesis, University of Hawai'i at Mānoa, Honolulu.

Starck, W. A., and W. P. Davis. 1966. Night habits of fishes of Alligator Reef, Florida. Ichthyologica 38:313-356.

Taylor, J. D. 1971. Reef associated molluscan assemblages in the western Indian Ocean. Symp. Zool. Soc. Lond. 28:501-534.

Thomassin, B. A., M. H. Vivien, and P. Vitiello. 1976. Distribution de la meiofaune et de la macrofaune des sables coralliens de la retenue d'eau epirecifale du Grand Recif de Tulear (Madagascar). J. Exp. Mar. Biol. Ecol. 22:31-53.

\section{Appendix 1}

Numerical Densities of Benthic Taxa (Individuals per Square Meter) at Soft-Bottom Sampling Stations 1-9 (High-level Taxa of Some of the Abundant Groups Are Shown in Boldface)

\begin{tabular}{|c|c|c|c|c|c|c|c|c|c|}
\hline Taxa & 1 & $2^{\star *}$ & 3 & $4^{* *}$ & $5^{\star * \star}$ & 6 & 7 & 8 & 9 \\
\hline Platyhelminthes & - & 5.3 & - & $一$ & 21.2 & 15.9 & 10.6 & - & 5.3 \\
\hline Oligochaeta & 74.2 & 58.3 & 63.6 & - & 31.8 & 47.7 & 63.6 & 26.5 & 68.9 \\
\hline Polychaeta & $1,934.5$ & $1,176.6$ & $2,438.0$ & 524.7 & $2,183.6$ & $1,823.2$ & $1,213.7$ & $5,676.3$ & $3,646.4$ \\
\hline Aphroditidae & - & - & 15.9 & - & - & - & - & 5.3 & 10.6 \\
\hline Capitellidae & 116.6 & 一 & 132.5 & - & 15.9 & 31.8 & 21.2 & 238.5 & 10.6 \\
\hline Chrysopetalidae & - & - & - & - & - & - & - & - & 10.6 \\
\hline Eunicidae & - & - & 42.4 & - & 26.5 & - & 10.6 & 15.9 & - \\
\hline Glyceridae & - & - & $\ldots$ & - & 15.9 & - & - & - & - \\
\hline Hesionidae & - & - & - & $\longrightarrow$ & 63.6 & - & 37.1 & 10.6 & - \\
\hline Lumbrineridae & 15.9 & 26.5 & 174.9 & - & 63.6 & - & 37.1 & 185.5 & 5.3 \\
\hline Magelonidae & 227.9 & - & 169.6 & 323.3 & - & 318.0 & 37.1 & 710.2 & 47.7 \\
\hline Nephtyidae & 10.6 & 15.9 & 10.6 & - & - & 5.3 & - & 5.3 & 10.6 \\
\hline Nereidae & - & 10.6 & - & 15.9 & - & - & - & - & - \\
\hline Onuphidae & 10.6 & - & - & 143.1 & - & 31.8 & 5.3 & 10.6 & 5.3 \\
\hline Opheliidae & 726.1 & - & 943.4 & 37.1 & 143.1 & - & 53.0 & $1,966.3$ & - \\
\hline Paraonidae & 455.8 & - & 662.5 & - & - & 858.6 & 630.7 & $2,226.0$ & $3,206.5$ \\
\hline Phyllodocidae & - & - & - & - & 106.0 & - & - & - & - \\
\hline Pilargidae & 5.3 & - & - & - & - & - & - & - & - \\
\hline Pisionidae & - & 339.2 & - & - & 5.3 & - & - & - & - \\
\hline Sabellidae & - & - & - & - & 5.3 & - & - & - & - \\
\hline Spionidae & 121.9 & 15.9 & 180.2 & 5.3 & 132.5 & 567.1 & 90.1 & 174.9 & 333.9 \\
\hline Syllidae & 212.0 & 768.5 & 47.7 & - & $1,505.2$ & - & 280.9 & 15.9 & 5.3 \\
\hline Terebellidae & 31.8 & - & 58.3 & - & 100.7 & 10.6 & 10.6 & 111.3 & - \\
\hline Sipuncula & $5.6^{*}$ & - & $3.4^{*}$ & 79.5 & 15.9 & $20.9^{\star}$ & $4.1^{*}$ & $21.7^{*}$ & $8.1^{*}$ \\
\hline Pycnogonida & - & - & - & 31.8 & - & - & - & - & - \\
\hline Collembola & 5.3 & - & 42.4 & - & 15.9 & 15.9 & 15.9 & 37.1 & 21.2 \\
\hline
\end{tabular}


Appendix 1 (continued)

\begin{tabular}{|c|c|c|c|c|c|c|c|c|c|}
\hline Taxa & 1 & $2^{* *}$ & 3 & $4^{* *}$ & $5^{\star *}$ & 6 & 7 & 8 & 9 \\
\hline \multicolumn{10}{|l|}{ Crustacea } \\
\hline Maxillopoda & 227.9 & 95.4 & 270.3 & - & 63.6 & 233.2 & 270.3 & 572.4 & 964.6 \\
\hline Ostracoda 1 & 132.5 & - & 127.2 & - & - & 95.4 & 132.5 & 143.1 & 169.6 \\
\hline Ostracoda 2 & 90.1 & - & 15.9 & - & 47.7 & 116.6 & 100.7 & 164.3 & 715.5 \\
\hline Ostracoda 3 & - & 10.6 & - & - & - & - & - & - & - \\
\hline Copepoda & 5.3 & 84.8 & 127.2 & - & 15.9 & 21.2 & 37.1 & 265.0 & 79.5 \\
\hline \multicolumn{10}{|l|}{ Eumalacostraca } \\
\hline Stomatopoda & - & - & $8.5^{*}$ & - & - & $1.0^{*}$ & - & - & $1.0^{*}$ \\
\hline Decapoda & 461.1 & 190.8 & 583.0 & 31.8 & 143.1 & 482.3 & 556.5 & $1,181.9$ & $1,950.4$ \\
\hline Penaeidae & $1.5^{*}$ & - & $0.6^{*}$ & - & - & - & $1.5^{*}$ & - & - \\
\hline \multicolumn{10}{|l|}{ Caridea } \\
\hline Alpheidae & $3.1^{*}$ & - & $0.6^{*}$ & - & - & - & - & - & - \\
\hline Ogyrididae & 280.0 & - & - & - & - & $40.8^{*}$ & $15.3^{*}$ & $65.1^{*}$ & $6.1^{*}$ \\
\hline Pasiphaeidae & $13.3^{*}$ & - & $6.8^{*}$ & - & - & $5.6^{*}$ & $2.0^{*}$ & $1.3^{*}$ & - \\
\hline Juv. carideans & $11.7^{*}$ & - & $2.8^{*}$ & - & 21.2 & - & $4.1^{*}$ & $1.3^{*}$ & - \\
\hline \multicolumn{10}{|l|}{ Thalassinidea } \\
\hline Callianassidae & $30.6^{*}$ & - & $86.6^{*}$ & - & 10.6 & $15.3^{*}$ & $45.4^{*}$ & $7.7^{*}$ & $7.1^{*}$ \\
\hline \multicolumn{10}{|l|}{ Brachyura } \\
\hline Calappidae & $0.5^{*}$ & - & - & - & - & - & - & - & - \\
\hline Portunidae & $7.7^{*}$ & - & $13.0^{*}$ & 10.6 & 5.3 & $1.5^{*}$ & $5.1^{*}$ & $10.2^{\star}$ & - \\
\hline Crab megalops & $5.1^{*}$ & - & $1.7^{*}$ & 10.6 & 5.3 & $0.5^{*}$ & $3.1^{*}$ & $3.2^{\star}$ & - \\
\hline \multicolumn{10}{|l|}{ Peracarida } \\
\hline Mysida & 5.3 & - & - & - & - & 5.3 & - & 5.3 & 15.9 \\
\hline Tanaidacea & - & 5.3 & - & - & - & - & - & - & - \\
\hline Isopoda & 95.4 & 450.5 & 482.3 & - & 63.6 & 21.2 & 15.9 & 651.9 & 84.8 \\
\hline Anthuridae & 5.3 & 445.2 & 5.3 & - & - & 5.3 & - & 42.4 & 53.0 \\
\hline Munnidae & - & - & 434.6 & - & 58.3 & 5.3 & 5.3 & 588.3 & 10.6 \\
\hline Cryptoniscan larva & 90.1 & 5.3 & 42.4 & - & 5.3 & 10.6 & 10.6 & 21.2 & 21.2 \\
\hline Amphipoda & 747.3 & 424.0 & 890.4 & 15.9 & 757.9 & $1,102.4$ & 402.8 & $1,113.0$ & $1,468.1$ \\
\hline \multicolumn{10}{|l|}{ Gammaridea } \\
\hline Amphilochidae & 100.7 & - & 439.9 & - & 47.7 & - & 10.6 & 360.4 & 5.3 \\
\hline Aori & 15.9 & - & 90.1 & - & 5.3 & 10.6 & 5.3 & 106.0 & 95.4 \\
\hline Corophiidae & - & - & - & - & 328.6 & - & 5.3 & - & - \\
\hline phalidae & 625.4 & 413.4 & 349.8 & - & 355.1 & $1,086.5$ & 376.3 & 630.7 & $1,356.8$ \\
\hline Unid. Gammaridea & 5.3 & 10.6 & 10.6 & 15.9 & 10.6 & 5.3 & 5.3 & - & 10.6 \\
\hline Hyperiidea & - & - & - & - & 10.6 & - & - & - & - \\
\hline Caprellidea & - & - & - & - & - & - & - & 15.9 & - \\
\hline Gastropoda & 31.8 & - & 100.7 & 5.3 & 21.2 & 26.5 & 5.3 & 196.1 & - \\
\hline Architectonicidae & - & - & 5.3 & - & - & - & - & - & - \\
\hline Atyidae & 21.2 & - & 79.5 & - & - & 21.2 & $4.1^{\star}$ & 95.4 & $3.1^{*}$ \\
\hline Naticidae & 5.3 & - & $1.7^{*}$ & - & 5.3 & 5.3 & $5.1^{*}$ & $0.6^{*}$ & - \\
\hline Smaragdinellidae & 5.3 & - & 5.3 & - & 5.3 & - & 5.3 & 95.4 & - \\
\hline Terebridae & $26.5^{*}$ & - & $8.5^{*}$ & 5.3 & 5.3 & $4.1^{*}$ & $16.3^{*}$ & $50.4^{*}$ & $1.0^{\star}$ \\
\hline Sacoglossa & - & - & 5.3 & - & 5.3 & - & $\ldots$ & - & - \\
\hline Unid. gastropod & - & - & 5.3 & - & - & - & - & 5.3 & - \\
\hline Bivalvia & 116.6 & - & 62.7 & 31.8 & 26.5 & 74.1 & 203.7 & $1,613.8$ & 228.9 \\
\hline Limidae & 10.6 & - & - & - & - & - & - & 15.9 & - \\
\hline Lucinidae & - & - & 5.3 & - & 15.9 & - & 68.9 & 58.3 & 47.7 \\
\hline Pectinidae & - & - & $0.6^{*}$ & - & - & - & - & $2.6^{*}$ & $1.0^{\star}$ \\
\hline Tellinidae & 42.4 & - & $9.1^{*}$ & 15.9 & - & $42.3^{*}$ & $50.0^{*}$ & 249.1 & 63.6 \\
\hline Mactracea & 53.0 & - & 47.7 & 10.6 & 10.6 & 31.8 & 84.8 & $1,287.9$ & 116.6 \\
\hline Unid. bivalves & 10.6 & - & - & 5.3 & - & - & - & - & - \\
\hline Scaphopoda & - & - & - & - & - & - & $\ldots$ & 5.3 & - \\
\hline Echinodermata & 355.1 & 5.3 & 21.2 & - & 169.6 & 47.7 & 355.1 & 323.3 & 42.4 \\
\hline & 37.1 & - & 10.6 & - & 15.9 & 15.9 & - & 137.8 & 10.6 \\
\hline \multicolumn{10}{|l|}{ Echinoidea } \\
\hline Brissidae & 42.4 & - & - & - & 5.3 & - & 127.2 & 5.3 & 5.3 \\
\hline Clypeasteridae & 275.6 & 5.3 & 10.6 & - & 148.4 & 31.8 & 227.9 & 180.2 & 26.5 \\
\hline Chaetognatha & - & - & - & - & - & - & 5.3 & - & - \\
\hline
\end{tabular}


Appendix 1 (continued)

\begin{tabular}{|c|c|c|c|c|c|c|c|c|c|}
\hline Taxa & 1 & $2^{* *}$ & 3 & $4^{* *}$ & $5^{\star *}$ & 6 & 7 & 8 & 9 \\
\hline Enteropneusta & - & - & - & 159.0 & - & - & - & - & - \\
\hline $\begin{array}{l}\text { Cephalochordata } \\
\text { Eish }\end{array}$ & 95.4 & - & 63.6 & - & 10.6 & - & 5.3 & 37.1 & 5.3 \\
\hline Callionymidae & $2.6^{*}$ & - & $0.6^{\star}$ & - & - & $1.0^{*}$ & $1.0^{\star}$ & $1.0^{*}$ & - \\
\hline Bothidae & $0.5^{\star}$ & - & - & - & - & - & - & - & - \\
\hline Unid. fish & - & 1.0 & 一 & - & - & - & - & - & - \\
\hline Total number & $7,661.6$ & $4,564.3$ & $9,274.7$ & $1,478.7$ & $6,852.9$ & $7,182.4$ & $5,541.8$ & $21,585.2$ & $14,936.4$ \\
\hline
\end{tabular}

${ }^{*}$ Numerical density estimated using airlift sample.

** No airlift sample taken.

Appendix 2

Fishes Observed over Soft-Bottom Transects Adjacent to Reef Edge Habitat

\begin{tabular}{|c|c|c|c|c|c|c|c|c|}
\hline \multirow[b]{3}{*}{ Species } & \multicolumn{4}{|c|}{ Day } & \multicolumn{4}{|c|}{ Night } \\
\hline & \multicolumn{2}{|c|}{$\begin{array}{l}0-25 \mathrm{~m} \\
(n=19)\end{array}$} & \multicolumn{2}{|c|}{$\begin{array}{l}50-75 \mathrm{~m} \\
(n=17)\end{array}$} & \multicolumn{2}{|c|}{$\begin{array}{l}0-25 \mathrm{~m} \\
(n=4)\end{array}$} & \multicolumn{2}{|c|}{$\begin{array}{c}50-75 \mathrm{~m} \\
(n=3)\end{array}$} \\
\hline & Freq. ${ }^{a}$ & No. ${ }^{b}$ & Freq. ${ }^{a}$ & No. ${ }^{b}$ & Freq.$^{n}$ & No. ${ }^{b}$ & Freq. ${ }^{a}$ & No. ${ }^{b}$ \\
\hline Xyrichtys pavo & 0.74 & 6.37 & 0.29 & 0.47 & - & - & - & - \\
\hline Parupeneus pleurostigna & 0.37 & 0.74 & - & - & 0.25 & 0.25 & 0.33 & 0.33 \\
\hline Mulloidicbtbys flavolineatus & 0.26 & 1.53 & - & - & 0.50 & 1.00 & 0.33 & 0.33 \\
\hline Arothron bispidus & 0.16 & 0.21 & - & - & - & - & - & - \\
\hline Aprion virescens & 0.11 & 0.21 & - & - & - & - & - & - \\
\hline Callionymus decoratus & 0.11 & 0.16 & 0.06 & 0.12 & - & - & - & - \\
\hline Parupeneus porpbyreus & 0.11 & 0.11 & - & - & - & - & - & - \\
\hline Seriola dumerili & 0.11 & 0.37 & - & - & - & - & - & - \\
\hline Tracbinocepbalus myops & 0.11 & 0.16 & 0.29 & 0.29 & - & - & - & 一 \\
\hline Acantburus dussumieri & 0.05 & 0.21 & - & 一 & - & - & - & - \\
\hline Acantburus olivaceus & 0.05 & 0.05 & - & - & - & - & - & - \\
\hline Botbus mancus & 0.05 & 0.05 & 0.12 & 0.12 & - & - & - & - \\
\hline Canthigaster coronata & 0.05 & 0.05 & - & - & - & - & - & - \\
\hline Callechelys luteus & 0.05 & 0.11 & 0.12 & 0.12 & - & 一 & - & - \\
\hline Caranx melampygus & 0.05 & 0.16 & 0.12 & 5.94 & - & - & 0.33 & 1.67 \\
\hline Chaetodon fremblii & 0.05 & 0.11 & - & - & - & - & - & - \\
\hline Cymolutes lechuse & 0.05 & 0.32 & 0.06 & 0.06 & - & - & - & - \\
\hline Mulloidicbtbys pfugeri & 0.05 & 1.84 & - & - & - & 一 & - & - \\
\hline Mulloidicbtbys vanicolensis & 0.05 & 0.16 & - & - & 0.50 & 2.50 & 0.33 & 0.33 \\
\hline Scomberoides lysan & 0.05 & 0.05 & - & - & - & - & - & - \\
\hline Ariosoma marginatus & - & - & 0.06 & 0.06 & 0.25 & 0.50 & - & - \\
\hline Lutjanus kasmira & - & - & - & - & 1.00 & 11.00 & - & - \\
\hline Fistularia conmersonii & - & - & - & - & 0.50 & 0.75 & 0.33 & 0.33 \\
\hline Lutjanus fulvus & - & - & - & - & 0.25 & 0.50 & - & - \\
\hline Apogon species & - & - & - & - & 0.25 & 0.25 & - & - \\
\hline Sphyraena acutipinnis & - & - & - & - & 0.25 & 0.25 & - & - \\
\hline Spbyma lewini & - & - & - & - & 0.25 & 0.25 & - & - \\
\hline Upeneus taeniopterus & - & - & - & - & 0.25 & 0.25 & - & - \\
\hline Caranx sexfasciatus & - & - & - & - & - & - & 0.33 & 2.00 \\
\hline Caranx ignobilis & - & - & - & 一 & - & - & 0.33 & 0.33 \\
\hline Mean no. $/ 5,000 \mathrm{~m}^{2}$ & & 12.95 & & 7.29 & & 17.50 & & 5.33 \\
\hline Standard deviation & & 12.61 & & 24.44 & & 3.30 & & 5.77 \\
\hline Diversity $\left(H^{\prime}\right)$ & & 1.86 & & 0.75 & & 1.51 & & 1.59 \\
\hline Total raw number & & 246 & & 123 & & 70 & & 16 \\
\hline
\end{tabular}

"Fraction of all visual censuses in which the species was observed.

${ }^{b}$ Mean number per $5,000 \mathrm{~m}^{2}$ (25 by $200 \mathrm{~m}$ transect). 


\section{Appendix 3}

Numerical Percentage (N), Volumetric Percentage (V), and Frequency of Occurrence (F) of Prey Taxa in the Diets of Fishes Coilected in the Soft-Bottom Habitat (Albula sp., Lutjanus kasmira, Lutjanus fulvus, Mulloidichtbys pflugeri, Xyrichtys pavo, Cymolutes Lechuse, and Callionymus decoratus)

\begin{tabular}{|c|c|c|c|c|c|c|c|c|c|c|c|c|c|c|c|c|c|c|c|c|c|}
\hline \multirow[b]{2}{*}{ Taxa } & \multicolumn{3}{|c|}{ Albula sp. } & \multicolumn{3}{|c|}{ L. kasmira } & \multicolumn{3}{|c|}{ L. futvus } & \multicolumn{3}{|c|}{ M. pflugeri } & \multicolumn{3}{|c|}{$X . p a v o$} & \multicolumn{3}{|c|}{ C. lectuse } & \multicolumn{3}{|c|}{ C. decoratiss } \\
\hline & $\mathrm{N}$ & V & $\mathrm{F}$ & $N$ & V & $\mathrm{F}$ & N & V & $\mathrm{F}$ & $\mathrm{N}$ & V & $\mathrm{F}$ & $\mathrm{N}$ & V & F & $\mathrm{N}$ & $\mathrm{V}$ & $\mathrm{F}$ & $\mathrm{N}$ & V & F \\
\hline Foraminifera & - & - & - & - & - & - & - & - & - & - & - & - & - & - & - & - & - & - & 6.2 & 3.3 & 6 \\
\hline & & & & & & & & & & & & & & & & & & & & & \\
\hline Capite & - & - & - & - & - & - & 1.3 & 1.1 & 16.7 & - & - & - & - & - & - & - & - & - & - & - & - \\
\hline Eunic & - & - & - & - & - & - & 1.3 & 0.2 & 8.3 & - & - & - & - & - & - & - & - & - & - & - & - \\
\hline Neph & - & - & - & 0.7 & 0.1 & 6.7 & - & - & - & - & - & - & - & - & - & - & - & - & - & - & \\
\hline Ophelii & 32.6 & 4.3 & 18.2 & 0.7 & 0.1 & 6.7 & 0.6 & 0.0 & 8.3 & - & - & - & - & - & - & - & - & - & 0.6 & 0.7 & 20 \\
\hline Parac & - & - & - & 0.7 & 0.1 & 6.7 & - & - & - & - & - & - & - & - & - & - & - & - & - & - & - \\
\hline Spion & 0.1 & 0.1 & 4.6 & 1.4 & 0.3 & 13.3 & - & - & - & - & - & - & - & - & - & 0.8 & 4.8 & 20 & - & - & \\
\hline Unid. poly & 0.3 & 0.6 & 9.1 & - & - & - & 0.6 & 27.1 & 8.3 & - & - & - & - & - & - & - & - & - & 0.3 & 0.3 & \\
\hline Sipuncu & - & - & - & - & - & - & - & - & - & - & - & - & - & - & - & - & - & - & 0.3 & 4.1 & \\
\hline Crustaceans & & & & & & & & & & & & & & & & & & & & & \\
\hline & - & - & - & 3.5 & 0.1 & 13.3 & 3.2 & 0.1 & 16.7 & - & - & - & 40.0 & 17.3 & 12.5 & 49.6 & 30.9 & 40 & 1.6 & 0.8 & 20 \\
\hline Ostra & - & - & - & - & - & - & - & - & - & - & - & - & - & - & - & - & - & - & 22.0 & 11.6 & \\
\hline Cope & - & - & - & - & - & - & - & - & - & - & - & - & - & - & - & - & - & - & 57.3 & 45.3 & \\
\hline Stom & 0.8 & 5.6 & 18.2 & 0.7 & 2.4 & 6.7 & - & - & - & 2.3 & 1.3 & 40 & - & - & - & - & - & - & - & - & \\
\hline Shrim & & & & & & & & & & & & & & & & & & & & & \\
\hline $\mathrm{Pe}$ & 0.3 & 1.7 & 9.1 & 0.7 & 19.3 & 6.7 & - & - & - & 7.6 & 9.4 & 100 & - & - & - & - & - & - & - & - & \\
\hline Carid & & 0.3 & 9. & 7.6 & 10.9 & 40 & 7.0 & 2.0 & 41.7 & & 0.4 & 6 & 0.8 & 0.7 & 12.5 & - & - & - & - & - & \\
\hline & 0.1 & 0.1 & 4.6 & - & - & - & 7.0 & 6.3 & 8.3 & 1.5 & 0.1 & 40 & - & - & - & - & - & - & - & - & \\
\hline & 38.2 & 18.8 & 81.8 & 70.1 & 25.3 & 86.7 & & 2.5 & 50 & 17.4 & 0 & 80 & 6.4 & 27.7 & 37.5 & 3.9 & 24.2 & 60 & 0.6 & 6.5 & 20 \\
\hline & 5 & 2.6 & 18.2 & 1.4 & 0.5 & 6.7 & 0. & 0.2 & 8.3 & 20.5 & 1.0 & 100 & - & - & - & 0.8 & 4.8 & 20 & - & - & \\
\hline Callianassidae & 0.1 & 0.1 & 4.5 & - & - & - & 1.9 & 0.4 & 16.7 & - & - & - & - & - & - & - & - & - & - & - & \\
\hline Crabs & & & & & & & & & & & & & & & & & & & & & \\
\hline Calappidae & & 0.3 & 4.6 & - & - & - & - & - & - & 5.3 & 2.6 & 60 & - & - & - & - & - & - & - & - & \\
\hline & & & & & 1.0 & & & 5.9 & 50.0 & & & & 2.4 & 20.1 & 37.5 & 0.8 & 7.7 & 20 & - & - & \\
\hline & 2. & 15.7 & & 3 & 18.3 & 13.3 & - & - & - & 7.6 & 7.3 & 10 & - & - & - & - & - & - & - & - & \\
\hline P. sa & 1.5 & 5.5 & 27.3 & 0.7 & 1.5 & 6.7 & - & - & - & 8.3 & 3.3 & 100 & - & - & - & - & - & - & - & - & \\
\hline & - & - & - & - & - & - & & & & - & - & - & - & - & - & - & - & & - & - & \\
\hline Tbal & - & - & - & - & - & - & 5.7 & 23.4 & 41.7 & - & - & - & - & - & - & - & - & - & - & - & \\
\hline Xanthi & 0.1 & 0.1 & 4.6 & - & - & - & 0.6 & 0.7 & 8.3 & - & - & - & - & - & - & - & - & - & - & - & \\
\hline & & 1 & 4. & - & - & - & & - & - & - & - & - & - & - & - & - & - & & - & - & \\
\hline $\mathrm{Pa}$ & 0. & 0 . & 4.6 & - & - & - & - & - & - & - & - & - & - & - & - & - & - & - & - & - & - \\
\hline Crab megalops & 1.3 & 0.8 & 4.6 & - & - & - & 4.4 & 2.3 & 25.0 & 2.3 & 0.2 & 60 & 0.8 & 0.4 & 12.5 & - & - & - & - & - & \\
\hline
\end{tabular}




\begin{tabular}{|c|c|c|c|c|c|c|c|c|c|c|c|c|c|c|c|c|c|c|c|c|c|}
\hline \multirow[b]{2}{*}{ Taxa } & \multicolumn{3}{|c|}{ Albula sp. } & \multicolumn{3}{|c|}{ L. kasmira } & \multicolumn{3}{|c|}{ L. fulvus } & \multicolumn{3}{|c|}{ M. pfugeri } & \multicolumn{3}{|c|}{$X . p a v o$} & \multicolumn{3}{|c|}{ C. lecluse } & \multicolumn{3}{|c|}{ C. decoratus } \\
\hline & $\mathrm{N}$ & $\mathrm{V}$ & $\mathrm{F}$ & $\mathrm{N}$ & $\mathrm{V}$ & F & $N^{\top}$ & $\mathrm{V}$ & $\mathrm{F}$ & $\mathrm{N}$ & $\mathrm{V}$ & $\mathrm{F}$ & $\mathrm{N}$ & V & F & $\mathrm{N}$ & V & $\mathbf{F}$ & $\mathrm{N}$ & $\mathrm{V}$ & $\mathrm{F}$ \\
\hline \multicolumn{22}{|l|}{ Peracarids } \\
\hline Amphilochidae & - & - & - & - & - & - & 1.9 & 0.2 & 25.0 & - & - & - & - & - & - & - & - & - & 0.3 & 0.4 & 20 \\
\hline Aoridae & - & - & - & - & - & - & - & - & - & - & - & - & - & - & - & - & - & - & 0.3 & 0.4 & 20 \\
\hline Corophiidae & - & - & - & - & - & - & - & - & - & - & - & - & 2.4 & 4.2 & 12.5 & - & - & - & - & - & - \\
\hline Phoxocephalidae & 3.4 & 0.1 & 50.0 & 4.9 & 0.2 & 33.3 & - & - & - & - & - & - & 2.4 & 1.0 & 25.0 & 5.4 & 3.4 & 40 & 1.9 & 2.5 & 80 \\
\hline Talitroidae & - & - & - & - & - & - & 38.0 & 10.4 & 8.3 & - & - & 一 & - & - & - & - & - & - & - & - & - \\
\hline Unid. Gammaridea & - & - & - & - & - & - & 2.5 & 0.1 & 8.3 & - & - & - & 42.4 & 17.5 & 25.0 & 38.8 & 24.2 & 20 & 0.6 & 0.8 & 20 \\
\hline Mysida & - & - & - & - & - & - & 0.6 & 0.1 & 8.3 & - & - & - & - & - & - & - & - & - & - & - & - \\
\hline crypto. larva & - & - & - & - & - & - & 1.3 & 0.2 & 16.7 & 一 & - & 一 & 0.8 & 3.5 & 12.5 & - & - & - & 2.5 & $2.0^{\circ}$ & 60 \\
\hline \multicolumn{22}{|l|}{ Gastropods } \\
\hline Architectonicidae & 0.1 & 0.1 & 4.6 & - & - & - & - & - & - & - & - & - & - & - & - & - & - & - & - & - & - \\
\hline Atyidae & & 0.1 & 9.1 & - & - & - & - & - & - & - & - & - & - & - & - & - & - & - & 1.2 & 3.3 & 40 \\
\hline Naticidae & 0.3 & 0.1 & 9.1 & - & - & - & - & - & - & - & - & - & - & - & - & - & - & - & - & - & - \\
\hline Smaragdinellidae & - & - & - & - & - & - & - & - & - & - & - & - & - & - & - & - & - & - & 0.3 & 0.8 & 20 \\
\hline \multicolumn{22}{|l|}{ Bivalves } \\
\hline Pectinidae & 0.3 & 1.2 & 4.6 & - & - & - & - & - & - & - & - & - & - & - & - & - & - & - & 1.2 & 6.5 & 20 \\
\hline Tellinidae & 0.8 & 3.0 & 9.1 & - & - & - & - & - & - & - & - & - & - & - & - & - & - & - & - & - & - \\
\hline Mactracea & 0.6 & 0.1 & 13.6 & - & - & - & - & - & - & - & - & - & - & - & - & - & - & - & 1.6 & 8.2 & 60 \\
\hline Unid. bivalves & 1.0 & 1.7 & 9.1 & - & - & - & - & - & - & - & - & - & - & - & - & - & - & - & 0.3 & 1.6 & 20 \\
\hline \multicolumn{22}{|l|}{ Echinoderms } \\
\hline Clypeasteridae & 5.9 & 2.2 & 22.7 & - & - & - & - & - & - & - & - & - & - & - & - & - & - & - & 0.3 & 0.4 & 20 \\
\hline Enteropneusta & - & - & - & - & - & - & 0.6 & 1.2 & 8.3 & - & - & - & - & - & - & - & - & - & - & - & - \\
\hline Cephalochordata & 0.3 & 0.1 & 9.1 & - & - & - & - & - & - & - & - & - & - & - & - & - & - & - & - & - & - \\
\hline Fish & - & - & - & _ & _ & - & - & - & - & 3.0 & 9.4 & 60 & - & - & - & - & - & - & - & - & \\
\hline E. bawaiiensis & 0.3 & 1.3 & 9.1 & 2.1 & 4.8 & 6.7 & - & - & - & 1.5 & 5.9 & 20 & - & - & - & - & - & - & - & - & - \\
\hline T. mayops & - & - & - & 0.7 & 14.5 & 6.7 & - & - & - & 8.3 & 46.8 & 40 & - & - & - & - & - & - & - & - & - \\
\hline Fish unid. & 0.6 & 4.3 & 18.2 & - & - & - & 2.5 & 4.4 & 25.0 & 6.1 & 8.8 & 80 & - & - & - & - & - & - & - & - & - \\
\hline
\end{tabular}




\section{Appendix 4}

Utilization of Soft-Bottom Habitats in Hanalei Bay by Fishes (Includes All Fishes Detected by All Methods on Sand Bottoms)

\begin{tabular}{|c|c|c|c|c|c|c|}
\hline Taxa & Primary & Secondary & Reef Edge & Center Bay & Black Hole & Surf Zone \\
\hline Spbyma lewini & $\mathrm{sr}$ & md & $N$ & & $\mathrm{D} \& \mathrm{~N}(\mathrm{sa})$ & \\
\hline Dasyatis spp. & $\mathrm{sr}$ & md & & & $\mathrm{D} \& \mathrm{~N}$ & \\
\hline Aetobatis narinari & si & $\operatorname{lp}$ & & & $\mathrm{D}$ & \\
\hline Albula sp. & $\mathrm{sr}$ & md & $\mathrm{D} \& \mathrm{~N}$ & & $\mathrm{D}$ & $\mathrm{D} \& \mathrm{~N}(\mathrm{sa})$ \\
\hline Callechelys luteus & sr & $\operatorname{csd}$ & & $\mathrm{N}$ & $\mathrm{N}$ & \\
\hline Ariosoma marginatus & $\mathrm{sr}$ & $\operatorname{csd}$ & $\mathrm{D} \& \mathrm{~N}$ & $\mathrm{D} \& \mathrm{~N}$ & $D \& N$ & $\mathrm{D} \& N$ \\
\hline Trachinocepbalus myops & st & $\operatorname{csd}$ & $\mathrm{D}$ & $\mathrm{D}$ & & \\
\hline Fistularia commersonii & sl & $\mathrm{rr}$ & $\mathrm{N}$ & & & \\
\hline Kublia sandvicensis & sl & $\mathrm{rl}$ & & & & $N$ \\
\hline Apogon spp. & $\mathrm{sl}$ & $\mathrm{rr}$ & $N$ & & $\mathrm{~N}$ & \\
\hline Alectis ciliaris & si & sp & & & & $\mathrm{N}$ \\
\hline Caranx ignobilis (sa) & si & $\mathrm{sp}$ & $\mathrm{N}$ & & $\mathrm{D} \& \mathrm{~N}$ & $\mathrm{~N}$ \\
\hline Caranx melampygus & si & sp, lp & $\mathrm{D} \& \mathrm{~N}$ & $\mathrm{D}$ & $\mathrm{D}$ & $D \& N$ \\
\hline Caranx sexfasciatus (sa) & si & $\mathrm{sp}$ & $\mathrm{N}$ & & $\mathrm{D}$ & $\mathrm{N}$ \\
\hline Pseudocaranx dentex & si & sp & $\mathrm{N}$ & & $\mathrm{D}$ & \\
\hline Scomberoides lysan & si & $\operatorname{lp}$ & $\mathrm{D}$ & & $\mathrm{D}$ & \\
\hline Seriola dumerilii & si & sp, lp & $\mathrm{D}$ & & $\mathrm{D}$ & $\mathrm{N}$ \\
\hline Aprion virescens & si & $\operatorname{lp}$ & $\mathrm{D}$ & & & \\
\hline Lutjanus fulvus & sl & $\mathrm{rl}$ & $\mathrm{N}$ & & $\mathrm{D} \& \mathrm{~N}$ & \\
\hline Lutjanus kasmira & sl & $\mathrm{rl}$ & $\tilde{N}$ & & $\mathrm{~N}$ & \\
\hline Mulloidicbtbys flavolineatus & sl & $\mathrm{rl}$ & $D \& N$ & & & \\
\hline Mulloidicbtbys vanicolensis & sl & $\mathrm{rl}$ & $\mathrm{D} \& \mathrm{~N}$ & & & $N(\mathrm{sa})$ \\
\hline Mulloidicbtbys pflugeri & sl & $\mathrm{rl}$ & $\mathrm{D}$ & & & \\
\hline Parupeneus pleurostigma & sl & $\mathrm{rl}$ & $\mathrm{D}$ & & & \\
\hline Parupeneus porpbyreus (sa) & sl & $\mathrm{rl}$ & & & & $\mathrm{D}$ \\
\hline Upeneus taeniopterzs & s.r & md & $\mathrm{N}$ & & $\mathrm{D}$ & $\mathrm{D}$ (sa) \\
\hline Mugil cephalus & sr & md & & & & $\mathrm{D} \& \mathrm{~N}$ \\
\hline Spbyraena acutipinnis & si & $1 \mathrm{p}$ & $\mathrm{N}$ & & & $\mathrm{N}$ \\
\hline Polydactylus sexfilis & $\mathrm{sr}$ & md & & & D? & $N(\mathrm{sa})$ \\
\hline Cymohutes lecluse & sr & $\operatorname{csd}$ & $\mathrm{D}$ & & & \\
\hline Xyricbtys pavo & $\mathrm{sr}$ & $\operatorname{csd}$ & $\mathrm{D}$ & & & \\
\hline Callionymus decoratus & $\mathrm{sr}$ & $\operatorname{csd}$ & $\mathrm{D}$ & $\mathrm{D}$ & & $\mathrm{D}$ \\
\hline Acantburus dussumieri & sl & rr & $\mathrm{D}$ & & & \\
\hline Acantburus olivaceus & sl & $\mathrm{rr}$ & $\mathrm{D}$ & & & \\
\hline Acantburus triostegus & sl & rr & $\mathrm{D}$ & & & $N$ \\
\hline Botbus mancus & $\mathrm{sr}$ & $\operatorname{csd}$ & $\mathrm{D}$ & $\mathrm{D}$ & & $\mathrm{D} \& \mathrm{~N}$ \\
\hline Engyprosopon bawaiizensis & $\mathrm{sr}$ & $\operatorname{csd}$ & $\mathrm{D}$ & $\mathrm{D}$ & & $\mathrm{D}$ \\
\hline Arotbron bispidus & sl & $\mathrm{rr}$ & $\mathrm{D}$ & & & \\
\hline Cantbigaster coronata & sl & $\mathrm{rr}$ & $\mathrm{D}$ & & & \\
\hline
\end{tabular}

Note: D, day; N, night; sa, subadults only; sr, sand-restricted; sl, sand-related; si, substrate-indifferent; csd, cryptic sand dweller; nd, mobile demersal; rr, reef-restricted; rl, reef-related; lp, large pelagic; sp, small pelagic. 